\title{
Projections of Precipitation Changes in Two Vulnerable Regions of São Paulo State, Brazil
}

\author{
Iracema F. A. Cavalcanti ${ }^{1}$, Lucí H. Nunes ${ }^{2}$, José A. Marengo ${ }^{3}$, Jorge L. Gomes ${ }^{1}$, Virginia P. Silveira1, \\ Marina S. Castellano
}

${ }^{1}$ Center of Weather Forecasting and Climate Studies/National Institute for Space Science (CPTEC/INPE), Cachoeira Paulista, S.P., Brazil

${ }^{2}$ State University of Campinas (UNICAMP), Cachoeira Paulista, S.P., Brazil

${ }^{3}$ National Center for Monitoring and Early Warning of Natural Disasters (CEMADEN), São José dos Campos, S.P., Brazil

Email: iracema.cavalcanti@cptec.inpe.br

How to cite this paper: Cavalcanti, I.F.A., Nunes, L.H., Marengo, J.A., Gomes, J.L., Silveira, V.P. and Castellano, M.S. (2017) Projections of Precipitation Changes in Two Vulnerable Regions of São Paulo State, Brazil. American Journal of Climate Change, 6, 268-293.

https://doi.org/10.4236/ajcc.2017.62014

Received: May 10, 2016

Accepted: May 9, 2017

Published: May 12, 2017

Copyright (C) 2017 by authors and Scientific Research Publishing Inc. This work is licensed under the Creative Commons Attribution International License (CC BY 4.0).

http://creativecommons.org/licenses/by/4.0/

\begin{abstract}
Weather and climate extremes are part of the natural variability. However, the frequency and intensity of precipitation extremes have increased in the globe following the global warming. Extreme precipitation impacts such as landslides and flooding with implications to vulnerability and adaptation are discussed for two regions of the state of São Paulo: the Metropolitan Region of Campinas and the Metropolitan Region of the Baixada Santista, located in southeastern South America. Simulations and projections obtained from four integrations of the Regional Eta model are analyzed to investigate the model behavior during the period of 1961-1990 and the projections within the period of 2011-2100. Uncertainties are discussed based on the standard deviation among the model spread. The projections show precipitation increase in the Metropolitan Region of Campinas during DJF for the near and distant future, while there are more uncertainties in the other seasons. In the Metropolitan Region of Baixada Santista, the precipitation increase is projected to all seasons, except JJA, when there is higher uncertainty. Daily rainfall indices suggest an increase of precipitation during the rainy days, but a reduction in the number of rainy days in both locations. The projections show a reduction of light rains and an increase of heavy rains at both regions. The model identifies the South Atlantic Convergence Zone and frontal systems as precipitation patterns associated with extremes in the two locations. The results can be useful for adaptation actions, since the regions are highly populated and have high vulnerabilities.
\end{abstract}

\section{Keywords}

Climate Change, Precipitation Extremes, Vulnerable Regions, Precipitation Indices, Regional Model 


\section{Introduction}

World's fast-growing urban areas, especially in developing countries, will likely suffer from the consequences of climate change, a major issue facing human societies. The projected impacts of climate change are likely to require some adaptation, which in turn is based on future projections of whether adaptive capacity assets will be drawn upon in times of need [1]. Adaptive response, a component of vulnerability, is dependent on a range of variables that operate at diverse scales [1]; among them, the frequency and intensity of extreme events which are in connection to population vulnerability, may favor natural disasters.

Although part of the natural system, extreme weather and climate events can cause impacts and major disruptions in natural and human systems. The level of impacts depends on the intensity of the change and also upon the capacity of the social groupings to avoid and/or to overcome their negative effects. Therefore, aspects such as poor infrastructure facilities, inexistent or weak institutional mechanisms to cope with extremes of climate variability and change such as lack of financial resources as well as socio-spatial disparities, are potential contributors to more severe impacts of extreme weather and climate events. Because such extreme events can reduce the economic growth and development and obstruct competitiveness; their evaluation must be part of a more complex task of assessing extremes to provide knowledge and to inform societal risk relevant to adaptation [2]. Components of vulnerability include exposure, sensitivity risk and resilience [3]. Adaptation measures can contribute to reducing risks making a society less vulnerable and more resilient to extremes.

Precipitation extremes over São Paulo state have been discussed in several studies [4] [5] [6] [7] [8]. Studies on observed precipitation extremes over Southeastern Brazil, where the São Paulo state is located, are numerous [9] [10] [11], among others. Model simulations of extremes over South America, including São Paulo state were presented in [12] and [13]. Most of these studies have shown that rainfall extremes have been increasing during the last five decades, and future projections show the similar trend. Uncertainties in future of precipitation projections over South America were discussed in [14] [15] [16]. The main source of uncertainty has been identified as the differences in physical parameterizations among different models and also the possible role of urbanization, something that is not yet well represented in climate models.

In the present study, the analyses are focused on two metropolitan regions of São Paulo state using a regional model and future projections results to provide information that can be useful to adaptation measures in face of the vulnerabilities of the sites. The Metropolitan Region of Campinas (MRC) and the Metropolitan Region of Baixada Santista (MRBS) are dynamic economic centers with rich ecosystems, but also low environmental threshold ${ }^{1}$, aggravated by the population increase and occupation of more risk-prone locations, such as hilly regions,

${ }^{1}$ Natural systems can withstand disruption only up to a certain threshold (or "tipping point") beyond which ecological discontinuities with socially, economically and environmentally unacceptable and possibly irreversible consequences are likely to occur (Ecologic Institute and SERI, 2010). 
which are affected by landslides or areas at risk of flooding. These actions led to relevant environmental changes during the last decades and made population more vulnerable to the impacts of extreme weather and climate.

São Paulo state is located in southeastern South America, in a region affected by the South Atlantic Convergence Zone (SACZ) [11] [17] [18] [19], a meteorological system that causes heavy and persistent precipitation. Heavy rainfall events over Southeastern Brazil have been associated with the SACZ and cold fronts [9]. In addition, these events can have the contribution of humidity flux from Amazonia, which is one of the sources of moisture to southeastern Brazil [20]. A review of large scale and synoptic systems influence on extreme precipitation over Southeastern Brazil is given in [21], where some cases during the first decade of $21^{\text {st }}$ century were discussed. Positive precipitation trend identified in São Paulo city, the largest city in Brazil, during the wet season from 1933 to 2010, was attributed in part to natural climate variability and also to the urbanization effects [7]. Besides the heat island effect, the influence of sea breeze intensification due to warmer nights on the positive precipitation trend was suggested by [6].

The Eta Regional model has been used in operational weather forecasting at the Center for Weather Forecasting and Climate Studies/National Institute for Space Research (CPTEC/INPE). This model has also been used in climate simulations and projections of climate change [6] [22] [23] [24] [25]. These projections were obtained from the Eta model downscaling of the HadCM3 with four integrations using the A1B scenario, and HadGEM2-ES, MIROC5 and BESM from CMIP5, using the RCPs 4.5 and 8.5 scenarios for 1961-1990, 2010-2040, 2041-2070 and 2071-2100. Precipitation, temperature and atmospheric circulation climatology of the base period were validated against observations in [22]. The four members simulated the seasonal difference between DJF and JJA, representing the typical SACZ pattern over tropical and subtropical South America.

The model results and observed data information are presented in Section 2. In Section 3, the geographic and socio-economic features of the two metropolitan regions are informed. Section 4 indicates the precipitation changes projected by the model in the regions, the member spread and uncertainties. Extreme precipitation indices are shown in Section 5, and precipitation patterns simulated by the model in cases of extreme monthly precipitation are discussed in Section 6. Conclusions are shown in Section 7.

\section{Data and Analyses}

The observed precipitation data were obtained from the São Paulo state data set archive: http://www.sigrh.sp.gov.br/cgi-bin/bdhm.exe/plu. Simulation and projections were analyzed from results of the Regional Eta model, with $40 \mathrm{~km}$ horizontal resolution and 38 vertical levels. The lateral boundary conditions were provided by the HadCM3 coupled climate model [26] with the A1B scenario for the future projections. Four members of simulations and projections, based on 
climate sensitivity were analyzed. Details of these integrations can be found in [22]. Maps of precipitation difference between two future periods (2011-2040) and (2070-2099) and the base period (1961-1990) are shown in percentages compared to the base period for the ensemble, ensemble plus and ensemble minus standard deviation among the members. Results from the four members were analyzed in the two locations, MRC and MRBS. Uncertainties are analyzed from the maps and considering members spread in the graphs.

Daily data from 1961 to 1990 (base period) and for three periods of the $21^{\text {st }}$ century (2011-2040, 2041-2070 and 2071-2098) were used to calculate the precipitation indices shown in Table 1 . The climatological monthly observed data and model results were used to obtain the annual cycle during the base period. Daily rain intensity was analyzed regarding class intervals of precipitation $<1 \mathrm{~mm}$ to $>51 \mathrm{~mm}$. Monthly data was used to calculate the Standardized Precipitation Index (SPI). This index identifies extreme wet/dry (SPI $\geq 2.0 /$ SPI $\leq-2.0$ ), severe wet/dry $(1.5 \leq \mathrm{SPI}<2.0) /(-2<\mathrm{SPI} \leq-1.5)$ and moderate wet/dry $(1.0 \leq \mathrm{SPI}<$ $1.5) /(-1.5<$ SPI $\leq-1.0)$ conditions. The anomalous precipitation patterns over South America associated with extreme wet monthly precipitation obtained from the 4 members in the 2 locations were analyzed in composites of precipitation anomalies for each season.

The vulnerability of each municipality is presented by means of the Social Vulnerability Index (SVI), developed by [27] which combines several variables of the 2010 Brazil census to indicate the vulnerability of each municipality. The SVI seeks to highlight the social inequality scenario in each metropolitan region, indicative of exclusion and social vulnerability, and was constructed using sixteen indicators grouped into three main dimensions: urban infrastructure, human capital and income and employment. Each dimension corresponds to a set of assets, resources or structures whose access, absence or failure indicate that the pattern of family life is low, suggesting, in extreme cases, the lack of access and non-compliance of social rights. Each variable has a relative weight, revealing their importance for the whole index.

The first dimension, the urban infrastructure vulnerability, reflects the conditions of access to basic sanitation and urban mobility and has three variables, each one with a weight in the index: percentage of people in households with inadequate water and sewage (0.3); percentage of population living in households without regular waste collection services (0.3); percentage of people living in households below poverty estimate and who spend more than one hour a day commuting (0.4). The second dimension, human capital, involves health and education

Table 1. Daily precipitation indices.

\begin{tabular}{ccc}
\hline SDII & Mean Precipitation of rainy days $>1 \mathrm{~mm}$ & $\mathrm{~mm} /$ day \\
SDII_10 & Mean Precipitation of days $\geq 10 \mathrm{~mm}$ & $\mathrm{~mm} /$ day \\
R1 & Number of rainy days & $\%$ \\
R10 & Number of days with precipitation $\geq 10 \mathrm{~mm}$ & $\%$ \\
\hline
\end{tabular}


and has 8 indicators, each one weighted 0.125 . The third and last dimension, income and employment, is composed of five indicators, each one weighted 0.2. The combination of the variables allows a unique value of exclusion and social vulnerability to the cities of the metropolitan regions. The SVI ranges between 0 and 1 , the closer to 1 , the greater the social vulnerability of a given municipality. Classes of social vulnerability are: $0-0.2$ very low; $0.2-0.3$ low; $0.3-0.4$ medium; 0.4 - 0.5 high; and above 0.5 very high.

\section{The Metropolitan Regions-Geographical and Socio-Economic Features}

\subsection{The Metropolitan Region of Campinas (MRC)}

Created in 19 June 2000, the Metropolitan Region of Campinas (MRC, Figure 1(a)) has 20 municipalities (one aggregated to the region in 2015 only), spread over $3,791 \mathrm{~km}^{2}$, with a population estimated in 3,094,181 inhabitants. The Gross Domestic Product (GDP) of the MRC is R $\$ 98.5$ billion and its Human Development Index (HDI), 0.792 [27]. The MRC is a center for research and development of science, technology and innovation in Brazil, concentrating more than 50 branches of the 500 largest companies in the world and accounting for $10 \%$ of Brazilian industrial production in various sectors, such as automotive, textile, metallurgy, food, pharmaceutical, petrochemical, telecommunications and electronics. Agriculture (fruits, coffee and sugar-cane) and services are also important activities in this region. The International Airport of Viracopos, in Campinas, is one of the most important of the country, especially due to its role in cargo transport. The area has undergone rapid social, economic and environmental transformations and despite its economic vitality, as in many other fast-growing urban areas, the unplanned growth of the city has led to an increasing inability to house the growing population and to provide adequate infrastructure. Part of the population lives in areas at great risk to natural disasters, including those expected to worsen with climate change, like floods.

Impacts produced by precipitation excess in Campinas, the main city of the

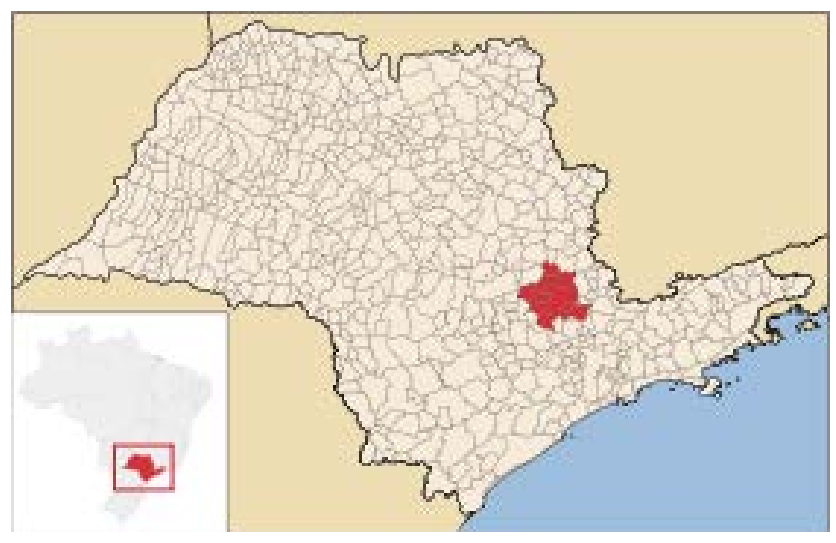

(a)

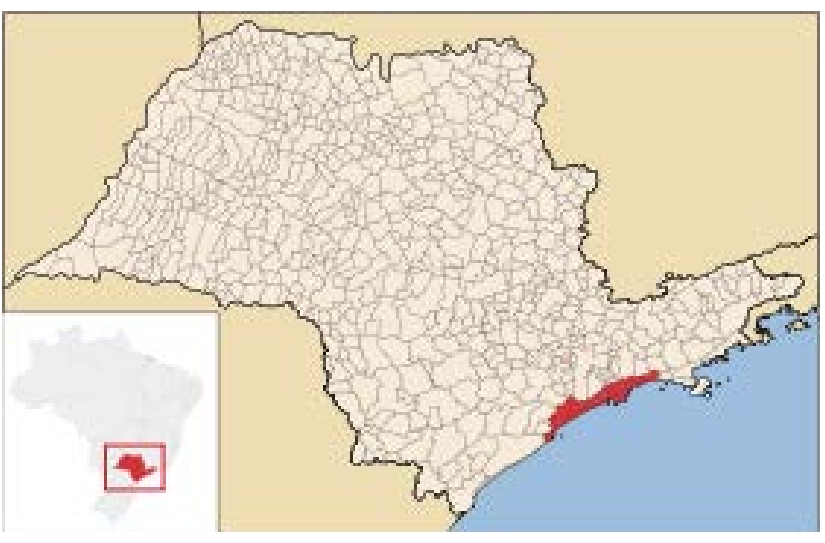

(b)

Figure 1. Locations of (a) Metropolitan Region of Campinas (MRC), (b) Metropolitan Region of Baixada Santista (MRBS) in relation to the state of São Paulo and Brazil (Source: Wikepedia). 
region, have increased in number and types between 1958 and 2007 and have affected all social classes [28]. During the same period, changes in the distribution of extreme precipitation events were also verified, especially in the last two decades, with increase in the annual totals and in the frequency of daily events above $50 \mathrm{~mm}$ [29]. Notwithstanding, the increase of impacts triggered by precipitation shows that the severe impacts were associated not only with the magnitude of the rain totals, but also with the increased exposure of the population [30]. Precipitation totals are variable within the area (Table 2), higher totals occurring during spring and summer periods. In order to evaluate the weight of the largest amounts in the precipitation time series, the Concentration Index [31], which considers the contribution of the days of greatest rainfall to the entire series, was applied to the area, for a period spanning from 1958 to 2003 [32]. The authors verified that rainfall was quite concentrated, as a large proportion of the total precipitation during the entire period (70\%) was registered on $25 \%$ of the days only. Death tolls due to weather events are on decrease after improvements on weather forecasting and preventive measures, but losses are still huge and many other challenges remain, like irregular occupation of risk-prone areas and lack of a responsive and efficient flood warning system. Although there are several individual studies related to these issues, there is a need to design and implement, in a coordinated way, a coherent and comprehensive understanding of the problems in the area.

\subsection{The Metropolitan Region of Baixada Santista (MRBS)}

The Metropolitan Region of Baixada Santista (MRBS), at the eastern edge of the Atlantic Ocean (Figure 1(b)), is the oldest settlement of Brazil, encompassing 9 municipalities spread in an area of $2421 \mathrm{~km}^{2}$, being home of 1,664,136 inhabitants. The region presents rich ecosystems and extensive climatic and topographic diversity, but the rapid urban expansion rate of the area in the last decades promoted a comprehensive disturb in its ecological dynamics (only 7\% of the original vegetation remain), as well as in the energy and water consumption. The Metropolitan Human Development Index (HDI) is 0.777 and the Gross Domestic Product (GDP) is $\mathrm{R} \$ 47.3$ billion [27]. The precipitation totals in the MRBS are high but variable spatially, as can be seen in Table 3. Concentration is more

Table 2. Average, maximum and minimum precipitation (1960-1999) to selected rain gauges within the MRC (Source: DAEE; CTH/USP; SIGRH, 2005).

\begin{tabular}{ccccccc}
\hline Municipality & Alt. $(\mathrm{m})$ & Lat. (S) & Lon. (W) & Avg. 1960-1999 (mm) & Annual Max. (mm) & Annual Min. (mm) \\
\hline Holambra & 600 & $23^{\circ} 38^{\prime}$ & $47^{\circ} 03^{\prime}$ & 1323.6 & $2,172.6(1983)$ & $878.9(1968)$ \\
Pedreira & 590 & $22^{\circ} 45^{\prime}$ & $46^{\circ} 56^{\prime}$ & 2456.2 & $2,456.2(1983)$ & $900.7(1963)$ \\
Itatiba & 780 & $23^{\circ} 01^{\prime}$ & $45^{\circ} 50^{\prime}$ & 2441.9 & $2,441.9(1983)$ & $587.7(1978)$ \\
Americana & 540 & $22^{\circ} 42^{\prime}$ & $47^{\circ} 17^{\prime}$ & 2017.8 & $2,017.8(1983)$ & $738.4(1968)$ \\
Cosmópolis & 560 & $22^{\circ} 40^{\prime}$ & $47^{\circ} 13^{\prime}$ & 1989.5 & $1,989.5(1983)$ & $770.6(1968)$ \\
Campinas & 600 & $22^{\circ} 47^{\prime}$ & $47^{\circ} 02^{\prime}$ & 2342.5 & $2,342.5(1983)$ & $885.7(1963)$ \\
\hline
\end{tabular}


Table 3. Average, maximum and minimum precipitation (1960-1999) to selected rain gauges within the MRBS (Source: DAEE; CTH/USP; SIGRH, 2005).

\begin{tabular}{ccccccc}
\hline Municipality & $\begin{array}{c}\text { Alt. } \\
(\mathrm{m})\end{array}$ & $\begin{array}{c}\text { Lat. } \\
(\mathrm{S})\end{array}$ & $\begin{array}{c}\text { Lon. } \\
(\mathrm{W})\end{array}$ & $\begin{array}{c}\text { Avg. 1960-1999 } \\
(\mathrm{mm})\end{array}$ & $\begin{array}{c}\text { Annual Max. } \\
(\mathrm{mm})\end{array}$ & $\begin{array}{c}\text { Annual Min. } \\
(\mathrm{mm})\end{array}$ \\
\hline Bertioga & 720 & $23^{\circ} 45^{\prime}$ & $46^{\circ} 08^{\prime}$ & 4657.4 & $7391.1(1947)$ & $1758.2(2001)$ \\
Cubatão & 5 & $23^{\circ} 52^{\prime}$ & $46^{\circ} 23^{\prime}$ & 2520.5 & $4138.6(1947)$ & $1754.8(1963)$ \\
Guarujá & 3 & $23^{\circ} 57^{\prime}$ & $46^{\circ} 11^{\prime}$ & 2306.4 & $5973.1(1947)$ & $1364.7(1938)$ \\
Itanhaém & 3 & $24^{\circ} 11^{\prime}$ & $46^{\circ} 48^{\prime}$ & 2132.4 & $3327.8(1966)$ & $358.1(2000)$ \\
Mongaguá & 20 & $24^{\circ} 05^{\prime}$ & $46^{\circ} 37^{\prime}$ & 2723.5 & $4129.2(1995)$ & $1422.5(2002)$ \\
Santos & 200 & $23^{\circ} 53^{\prime}$ & $46^{\circ} 13^{\prime}$ & 3375.6 & $5559.3(1947)$ & $1946.8(2001)$ \\
São Vicente & 10 & $23^{\circ} 57^{\prime}$ & $46^{\circ} 27^{\prime}$ & 2351.9 & $3176.1(1973)$ & $1425.5(2001)$ \\
\hline
\end{tabular}

acute during summer, which coincides with an increase of tourism activities and thus, exposes more people to the risk of floods and landslides. Evaluating how concentrated was daily rainfall from 1958 to 2003, [32] found that few events registered very high rainfall amounts. Concentrated amounts of rainfall can largely impact the affected areas, causing flooding, erosion, landslide; in some situations high precipitation can be associated with storm surges, that bring major loss of property and life, reduce the economic growth and obstruct competitiveness.

In some sectors of the MRBS the high deforestation rate associated with the occupation of sites next to rivers or steeply slopes and the intense precipitation episodes have caused major natural disasters, as a large number of people live in areas at risk of mass movements and flooding. This occupational pattern and the pollution generated by the industrial complexes affected the vegetation, which originally protected the slopes and soils, leading to erosion landslides, mudslides and floods. Deforestation also reduced the water retention capacity of the soil, increased continental runoff and contributed to biodiversity losses.

The GDP of the MRBS corresponds to approximately US $\$ 21.9$ billion and large-scale economic interests include the Port of Santos, the largest and more important of Latin America and the main logistic center of Brazil, as around a quarter of the products value traded in the country in the international market passes by this harbor. In addition, it is part of the largest system of road-rail transport and waterways (Tietê-Paraná) of the country and handles more than 90 million tons per year. The recent oil finds in the ultra-deep Pre-salt layer of Santos Basin is creating new demands for infrastructure, transport and communication, which might continue to exert strong pressure in this coastal sector (Governo do Estado de São Paulo, Secretaria de Desenvolvimento Metropolitano 2011).

\subsection{Social Vulnerability in MRC and MRBS}

Social vulnerability refers to the resilience of people when confronted by stresses, among them weather-related disasters. Inside the two metropolitan regions, dif- 
ferences of infrastructure, security and availability of public spaces influence the welfare levels of individuals and families. In Table 4 and Figure 2, that present the SVI for the municipalities of the MRC, one can see that all cities present low to medium social vulnerability. Four of them, including Campinas-the seat of the MR, regional leader on economic development and home of 1,080,999 people present the highest values of SVI for the region. Campinas has experienced fast social, economic and environmental changes and presents deficiencies in the infrastructure. The urbanization rate is high and partially uncontrolled and uncoordinated, resulting in disperses clusters over space. Because people are more scattered, the costs of infrastructure and public services tend to be higher [33] and might pose additional problems in a situation of danger. Also in the MRBS all municipalities present low to medium social vulnerability (Table 5, Figure 3). However, five in nine present the highest values of SVI for the region. Santos, the center of the MRBS is the only city that has very low SVI. The differences among the cities of the MRBS expose the fact that although the Metropolitan Region should operate in a combined way to promote an equal and comprehensive development, important internal differences concerning vulnerability remain within the area.

Table 4. Social vulnerability index for each municipality of the MRC.

\begin{tabular}{|c|c|c|}
\hline & Municipality & SVI (2010) \\
\hline 1 & Americana & 0.149 \\
\hline 2 & Artur Nogueira & 0.260 \\
\hline 3 & Campinas & 0.277 \\
\hline 4 & Cosmópolis & 0.205 \\
\hline 5 & Engenheiro Coelho & 0.284 \\
\hline 6 & Holambra & 0.117 \\
\hline 7 & Hortolândia & 0.308 \\
\hline 8 & Indaiatuba & 0.154 \\
\hline 9 & Itatiba & 0.178 \\
\hline 10 & Jaguariúna & 0.198 \\
\hline 11 & Monte Mor & 0.326 \\
\hline 12 & Nova Odessa & 0.177 \\
\hline 13 & Paulínia & 0.211 \\
\hline 14 & Pedreira & 0.137 \\
\hline 15 & Santa Bárbara D’Oeste & 0.174 \\
\hline 16 & Santo Antônio de Posse & 0.216 \\
\hline 17 & Sumaré & 0.244 \\
\hline 18 & Valinhos & 0.179 \\
\hline 19 & Vinhedo & 0.175 \\
\hline
\end{tabular}



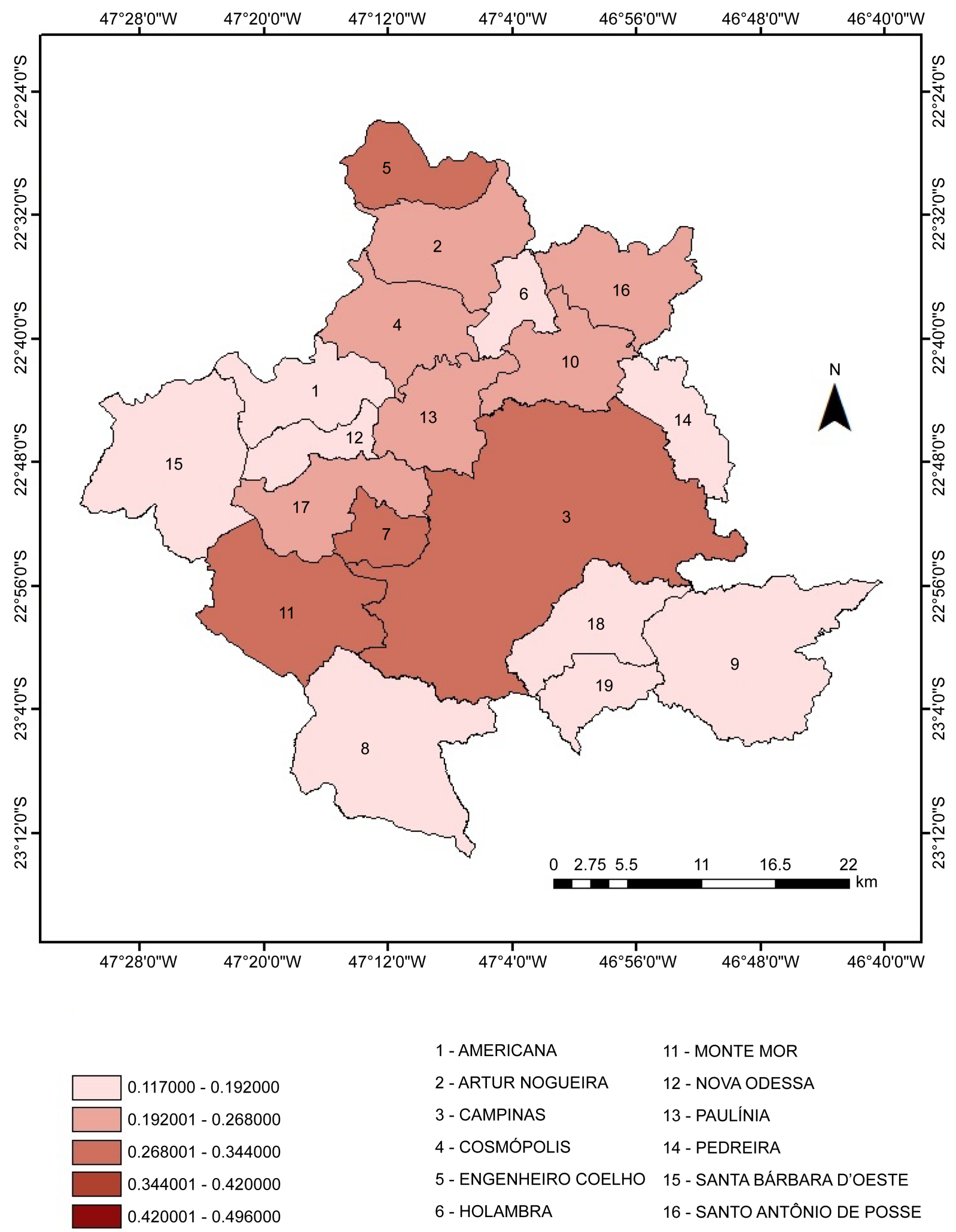

1 - AMERICANA
2 - ARTUR NOGUEIRA
3 - CAMPINAS
4 - COSMÓPOLIS
5 - ENGENHEIRO COELHO
6 - HOLAMBRA
7 - HORTOLÂNDIA
8 - INDAIATUBA
9 - ITATIBA
10 - JAGUARIÚNA

11 - MONTE MOR
12 - NOVA ODESSA
13 - PAULÍNIA
14 - PEDREIRA
15 - SANTA BÁRBARA D'OESTE
16 - SANTO ANTÔNIO DE POSSE
17 - SUMARÉ
18 - VALINHOS
19 - VINHEDO

Figure 2. Social vulnerability index for the municipalities of MRC. 
Table 5. Social vulnerability index for each municipality of the MRBS.

\begin{tabular}{lccc}
\hline & Municipality & SVI (2000) & SVI (2010) \\
\hline 1 & Bertioga & 0.288 & 0.224 \\
2 & Cubatão & 0.353 & 0.292 \\
3 & Guarujá & 0.376 & 0.285 \\
4 & Itanhaém & 0.359 & 0.250 \\
5 & Mongaguá & 0.411 & 0.273 \\
6 & Peruíbe & 0.372 & 0.245 \\
7 & Praia Grande & 0.405 & 0.319 \\
8 & Santos & 0.233 & 0.170 \\
9 & São Vicente & 0.398 & 0.311 \\
\hline
\end{tabular}

Reducing social vulnerability can decrease both human suffering and economic loss. As the two regions present high vulnerabilities regarding precipitation events leading to flooding and landslides, changes due to the global warming need to be assessed to improve adaptation actions. Therefore, in the next sections, future projections of precipitation are analyzed from model results, focusing in the two metropolitan regions.

\section{Precipitation Changes Projected by the Regional Eta Model in the Metropolitan Region of Campinas (MRC) and Metropolitan Region of Baixada Santista (MRBS)}

Results from the Eta-HadCM3 model simulations from the base period (1961-1990) and model projections for the future are discussed in this section. The annual cycle of observed and model ensemble precipitation in MRC and MRBS are shown in Figure 4. The annual cycles are reasonably well simulated, although with overestimated values in MRC and underestimated values in MRBS, where there is larger underestimation in the austral summer and autumn. The differences between the two annual cycles are likely related to the different precipitation regime between the two regions. In Figure 4, it is seen that at MRC, located relatively far from the ocean, the precipitation regime presents a seasonal contrast, with large amounts during summer, when a series of processes operate in the area bringing more moisture, and when there is development of the SACZ, while precipitation in winter, when the atmospheric circulation is different from summer, is primarily linked to the cold fronts. On the other hand, although MRBS is also affected by the SACZ, it presents lower inter- and intra seasonal variability and larger precipitation than MRC during the whole year as it is influenced by the humidity advection from the sea. In addition, the reduction from the summer to autumn and winter is gradual, while in MRC there is a greater reduction. The monthly differences between the future periods and the base period are indicated by the columns in Figure 4. There is a dominance of rainfall increase from late spring to early winter, in the three future periods, in 


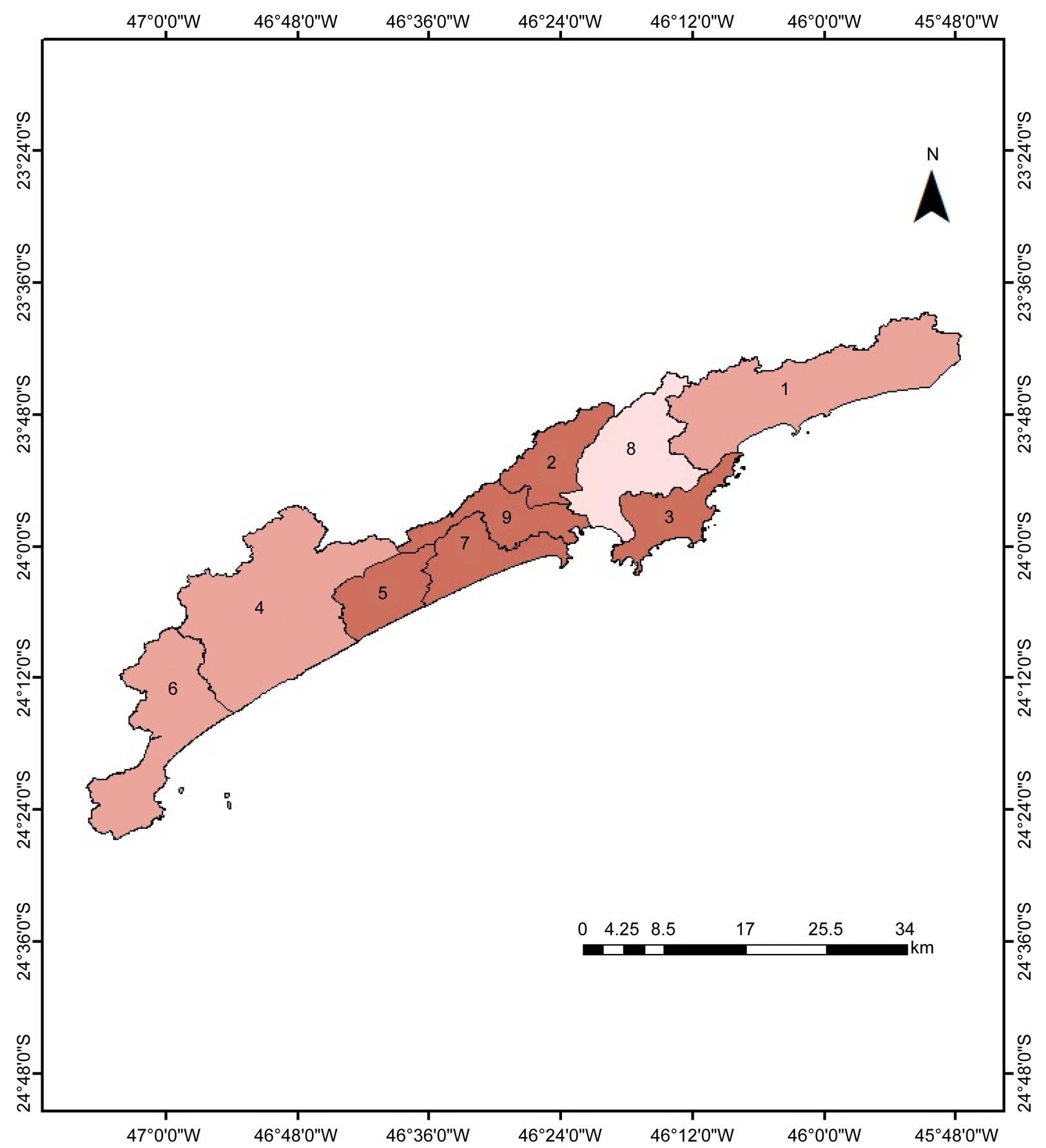

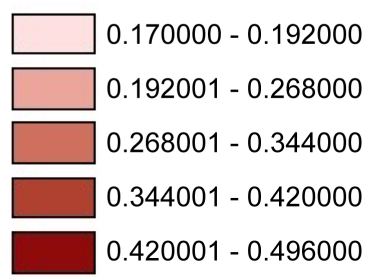

$\begin{array}{ll}1 \text { - BERTIOGA } & 6 \text { - PERUÍBE } \\ 2 \text { - CUBATO } & 7 \text { - PRAIA GRANDE } \\ 3 \text { - GUARUJÁ } & 8 \text { - SANTOS } \\ 4 \text { - ITANHAÉM } & 9 \text { - SÃO VICENTE } \\ 5 \text { - MONGAGUÁ } & \end{array}$

Figure 3. Social vulnerability index for the municipalities of MRBS. 


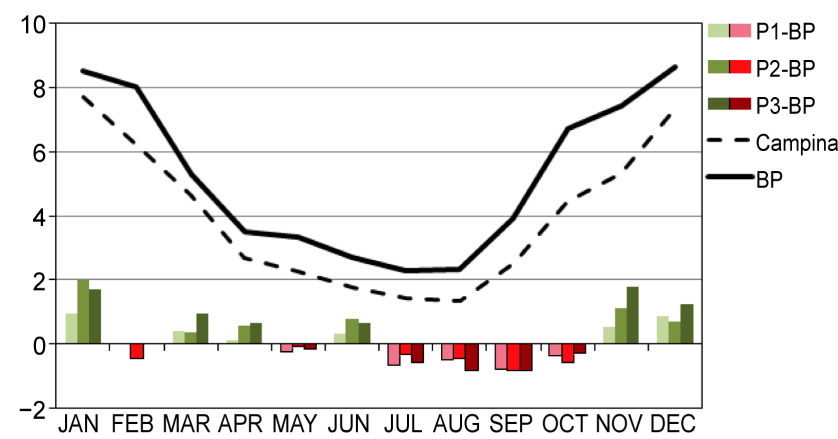

(a)

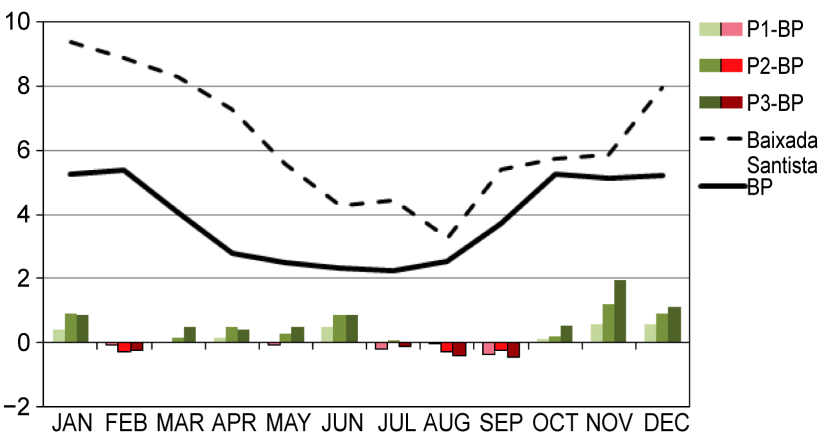

(b)

Figure 4. Annual cycle of precipitation. Model during Base Period (BP) of 1961-1990 (solid line). Observation during 1961-1990 (dashed line). Columns are the differences between future periods and base period. P1: (2011-2040) - (1961-1990), P2: (2041-2070) - (1961-1990), P3: (2070-2099) - (1961-1990). (a) MRC, (b) MRBS.

MRC. Reduced rainfall is projected from middle winter to middle spring. At MRBS small reductions are projected for August and September. From middle spring to early winter the projections show increased precipitation except in February and July, when there is a very small reduction. Then, in both locations, the rainy season is projected to be wetter and the dry season to be drier than in the base period.

Spatial changes in two future periods: near future (2011-2040) and distant future (2070-2099) compared to the base period (1961-1990) of MRC and MRBS are shown in Figures 5-8. The uncertainties are discussed in terms of the standard deviation among the members. The ensemble mean, ensemble mean plus or minus one standard deviation indicate large or small uncertainties and the members spread. In DJF (2011-2040) the ensemble mean indicates an increase of precipitation between $5 \%$ and $10 \%$ at MRC (Figure 5(a)). The increase interval is between $0 \%$ and $20 \%$, from the ensemble minus to the ensemble plus. During DJF (2070-2099) the range of increase is between $10 \%$ to $20 \%$ in the ensemble and between $0 \%$ to $30 \%$ from the ensemble minus to the ensemble plus (Figure 5(b)). At MRBS the projections also show precipitation increase for the ensemble between $0 \%$ and $5 \%$ in the majority of municipalities (Figure 5(c)). Compared to the MRC, the uncertainty is larger at MRBS, since the ensemble minus standard deviation indicates a reduction between $0 \%$ and $5 \%$ and the ensemble plus standard deviation indicates an increase between 5\% and 10\% (Figure 5(c)). The uncertainty at MRBS is reduced during DJF (2070-2099) since the ensemble, ensemble minus and ensemble plus indicate increases between $0 \%$ and 20\% (Figure 5(d)). Figure 9 shows the spread among the four members of precipitation differences between three future periods and the base period. At MRC all members show increased precipitation in the future periods during DJF, indicating a convergence in the model response and then more confidence on the results (Figure 9(a)). At MRBS there is convergence among the members on precipitation increase during the last two future time slices (Figure 9(b)).

In MAM (Figure 6(a)), the uncertainties range from $-10 \%$ to $20 \%$ at MRC during the period (2011-2040) and between $-5 \%$ and 30\% during (2070-2099), 

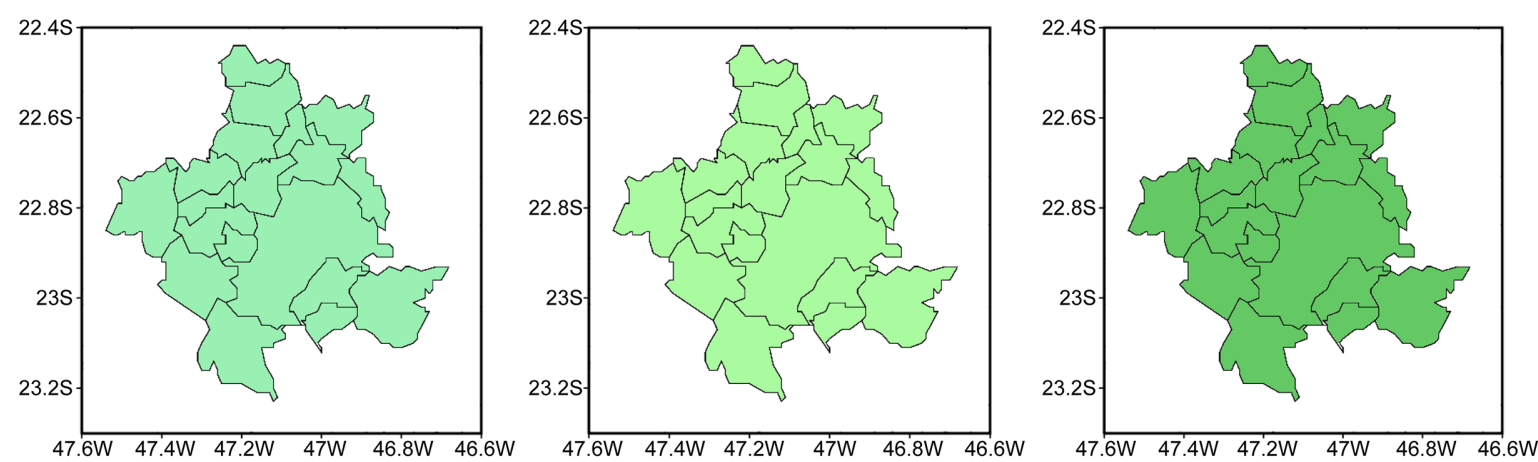

(a) DJF (2011-2040) - (1961-1990) MRC
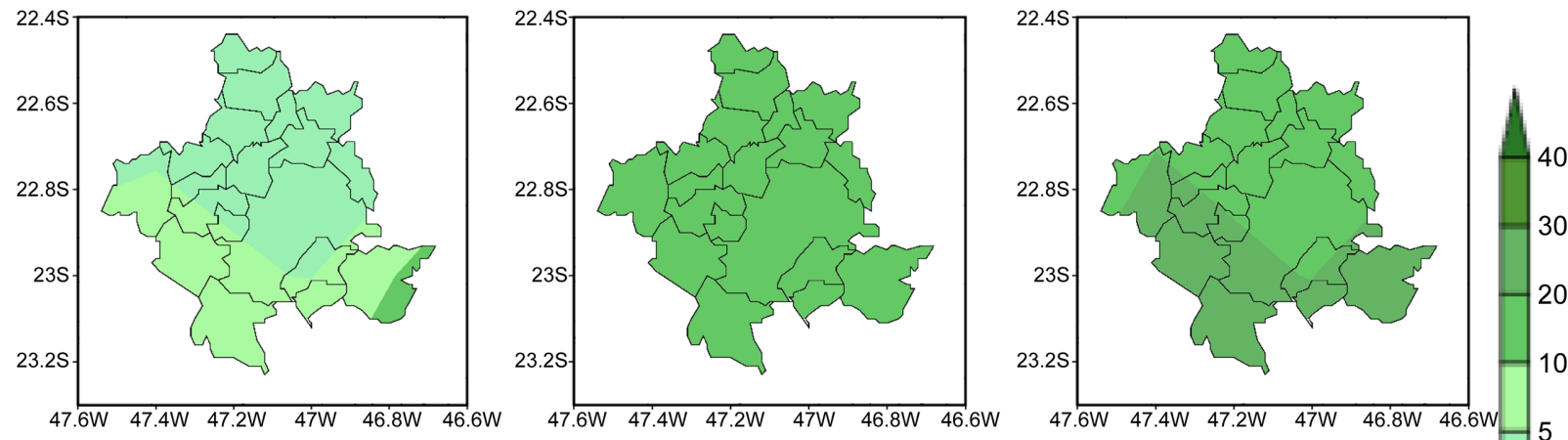

(b) DJF (2070-2099) - (1961-1990) MRC
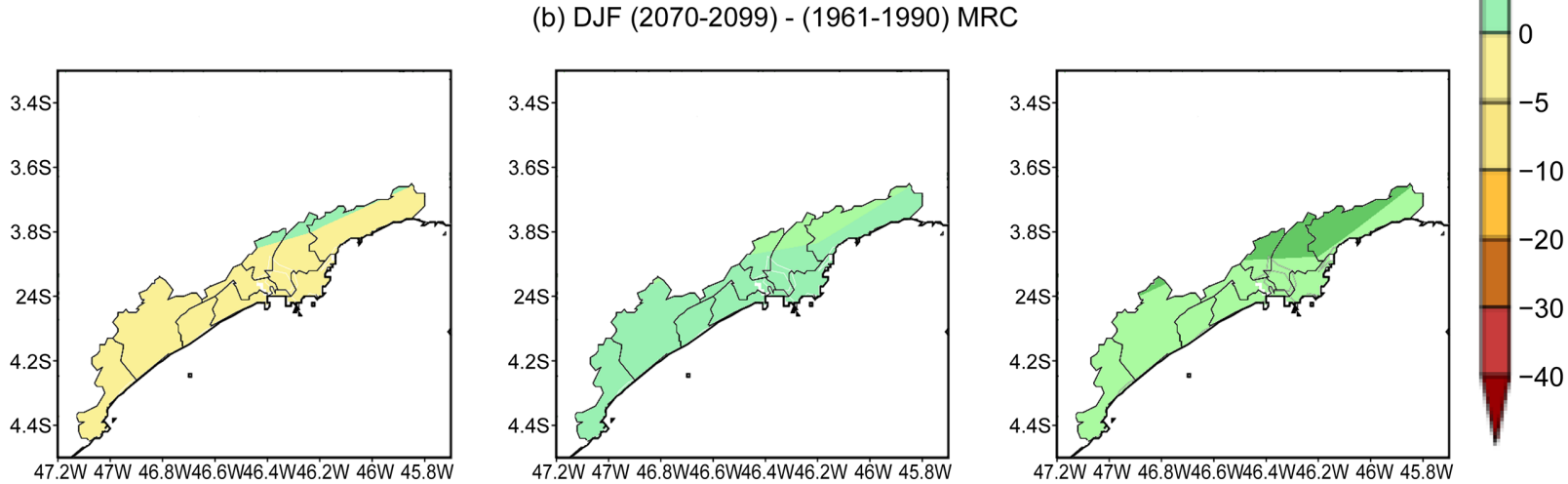

(c) DJF (2011-2041) - (1961-1990) MRBS
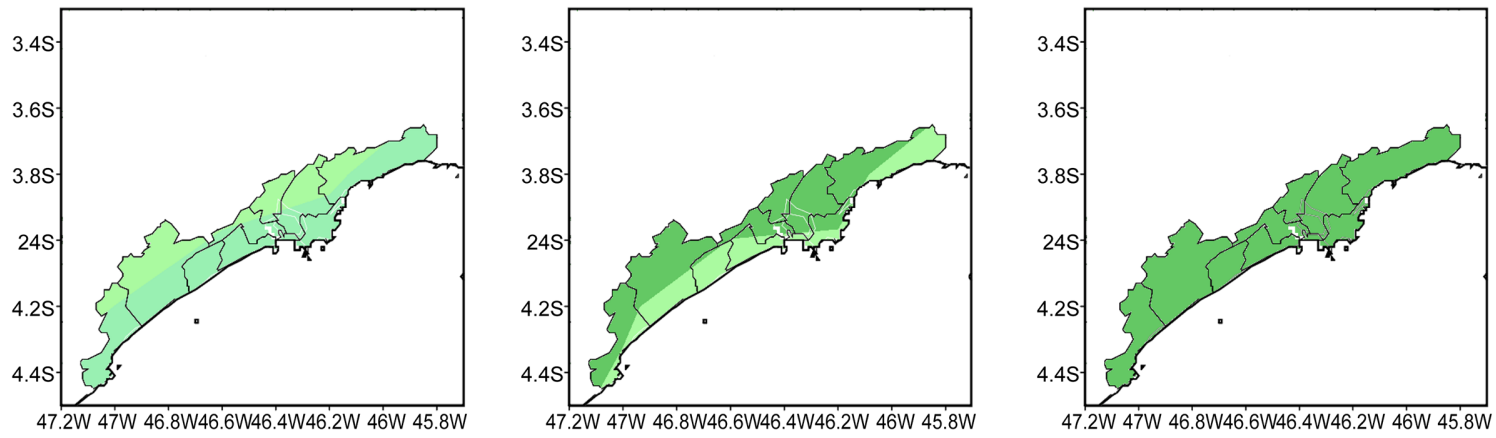

(d) DJF (2070-2099) - (1961-1990) MRBS

Figure 5. Difference of precipitation in DJF between future projections and the base period in \% for the ensemble minus standard deviation among members (left panel), ensemble (middle panel) and ensemble plus standard deviation among members (right panel). (a) (2011-2040) - (1961-1990) at MRC, (b) (2070-2099) - (1961-1990) at MRC, (c) (2011-2040) - (1961-1990) at MRBS, (d) (2070-2099) - (1961-1990) at MRBS. 

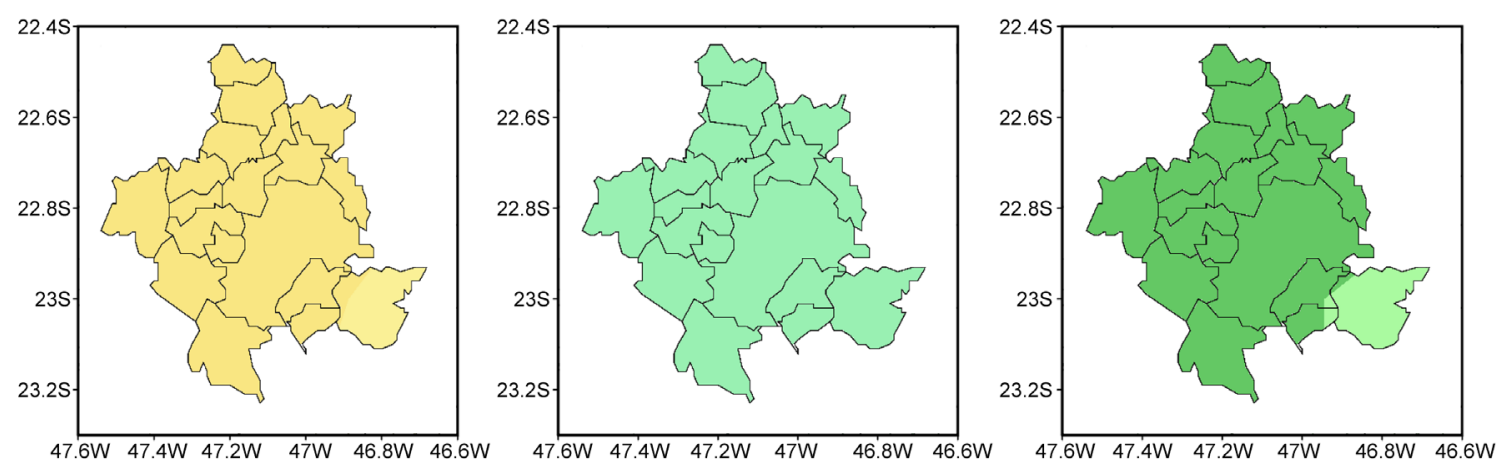

(a) MAM (2011-2040) - (1961-1990) MRC
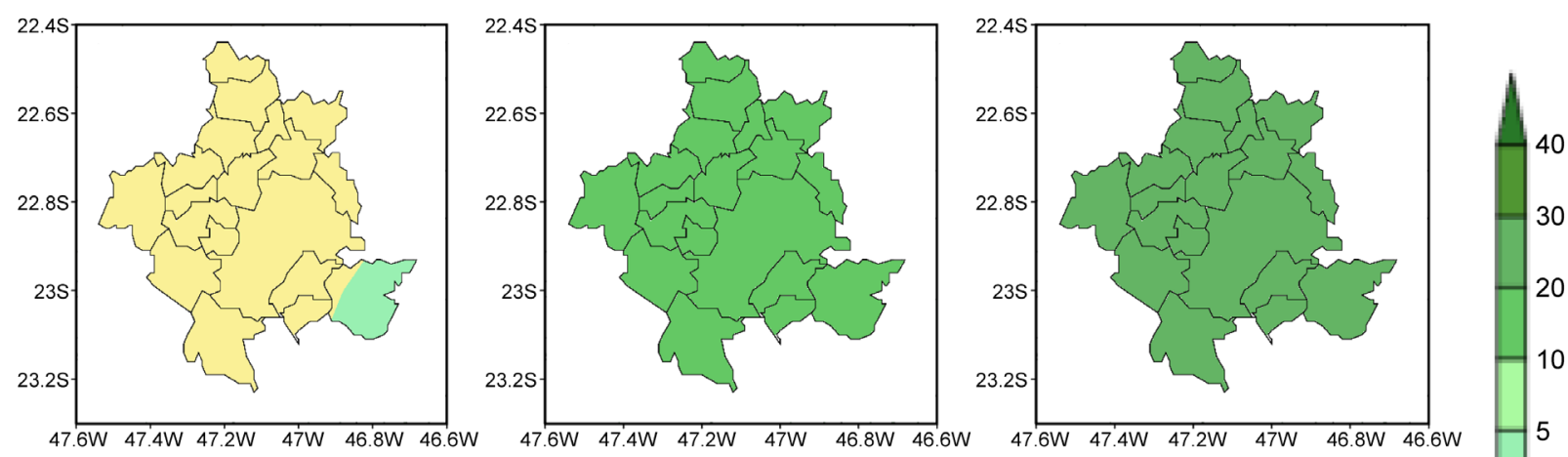

(b) MAM (2070-2099) - (1961-1990) MRC
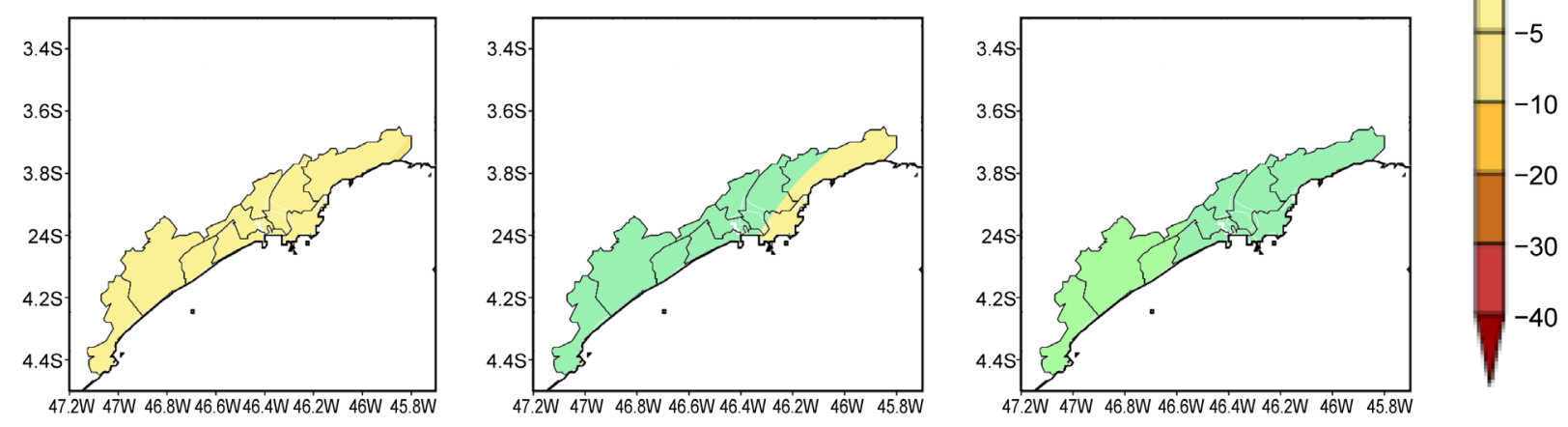

(c) MAM (2011-2040) - (1961-1990) MRBS
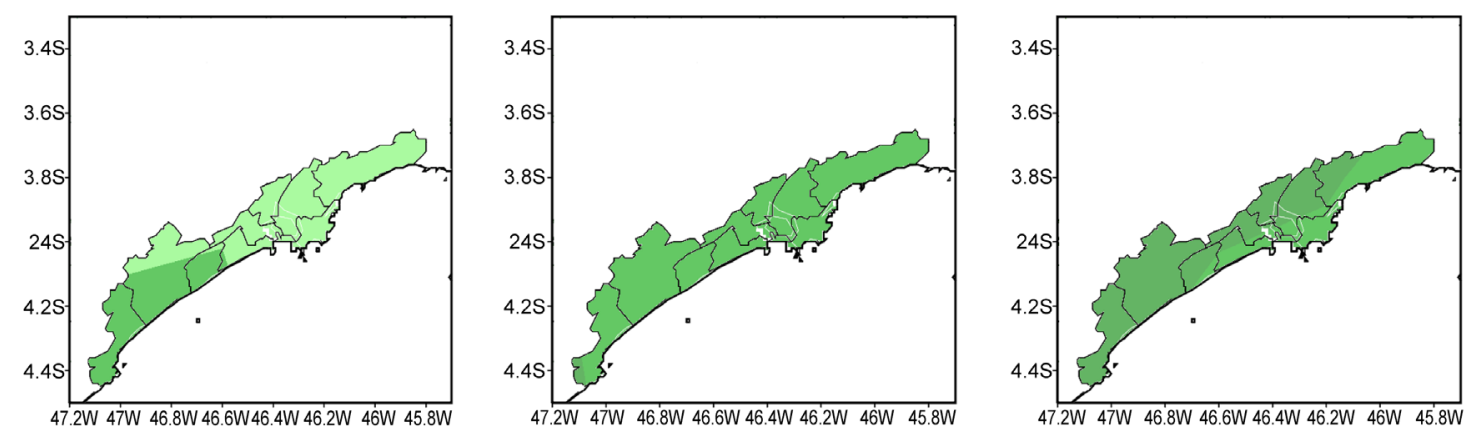

(d) MAM (2070-2099) - (1961-1990) MRBS

Figure 6. Difference of precipitation in MAM between future projections and the base period in \% for the ensemble minus standard deviation among members (left panel), ensemble (middle panel) and ensemble plus standard deviation among members (right panel). (a) (2011-2040) - (1961-1990) at MRC, (b) (2070-2099) - (1961-1990) at MRC, (c) (2011-2040) - (1961-1990) at MRBS, (d) (2070-2099) - (1961-1990) at MRBS. 

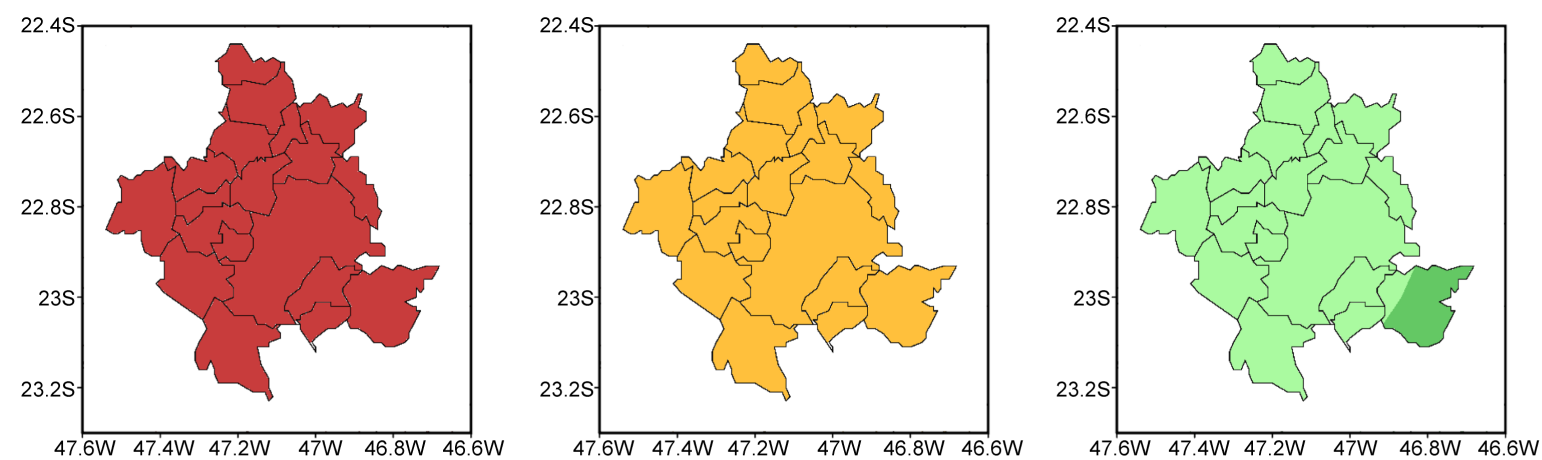

(a) JJA (2011-2040) - (1961-1990) MRC
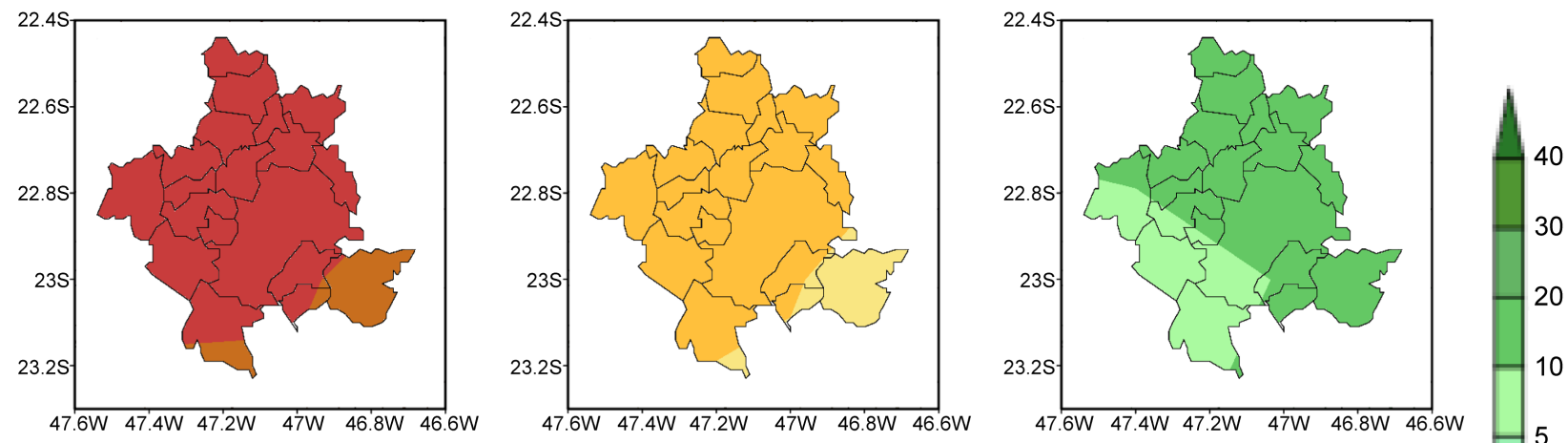

(b) JJA (2070-2099) - (1961-1990) MRC
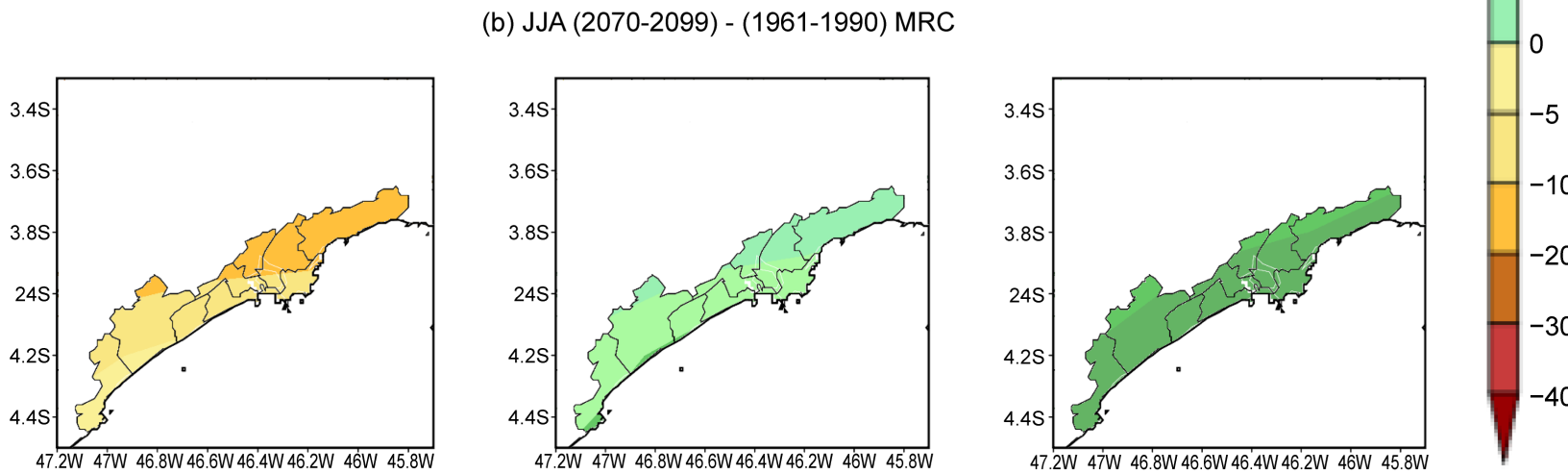

(c) JJA (2011-2040) - (1961-1990) MRBS
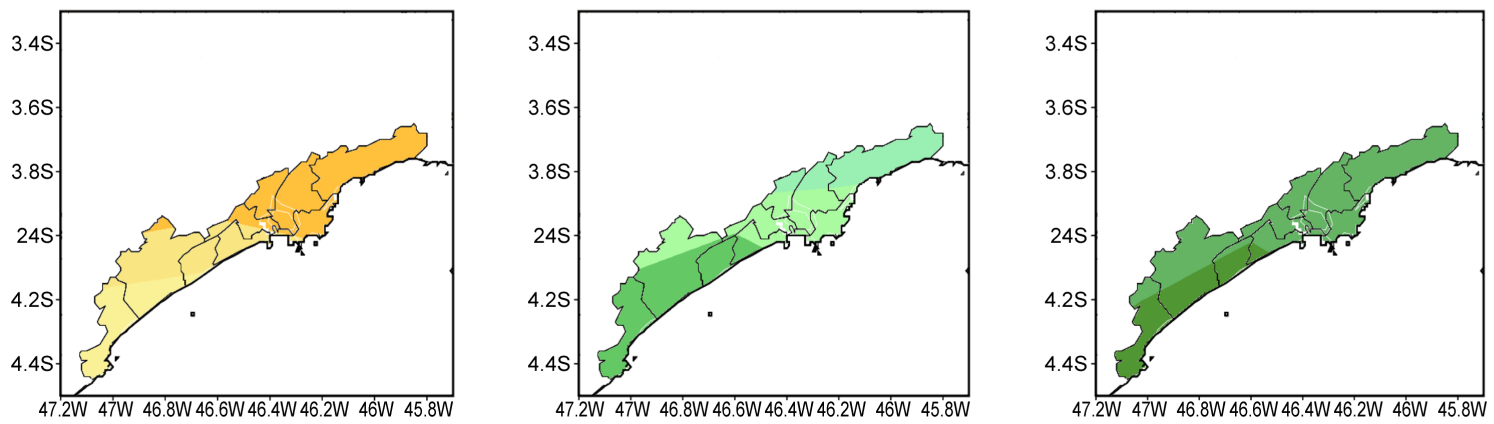

(d) JJA (2070-2099) - (1961-1990) MRBS

Figure 7. Difference of precipitation in JJA between future projections and the base period in $\%$ for the ensemble minus standard deviation among members (left panel), ensemble (middle panel) and ensemble plus standard deviation among members (right panel). (a) (2011-2040) - (1961-1990) at MRC, (b) (2070-2099) - (1961-1990) at MRC, (c) (2011-2040) - (1961-1990) at MRBS, (d) (2070-2099) - (1961-1990) at MRBS. 

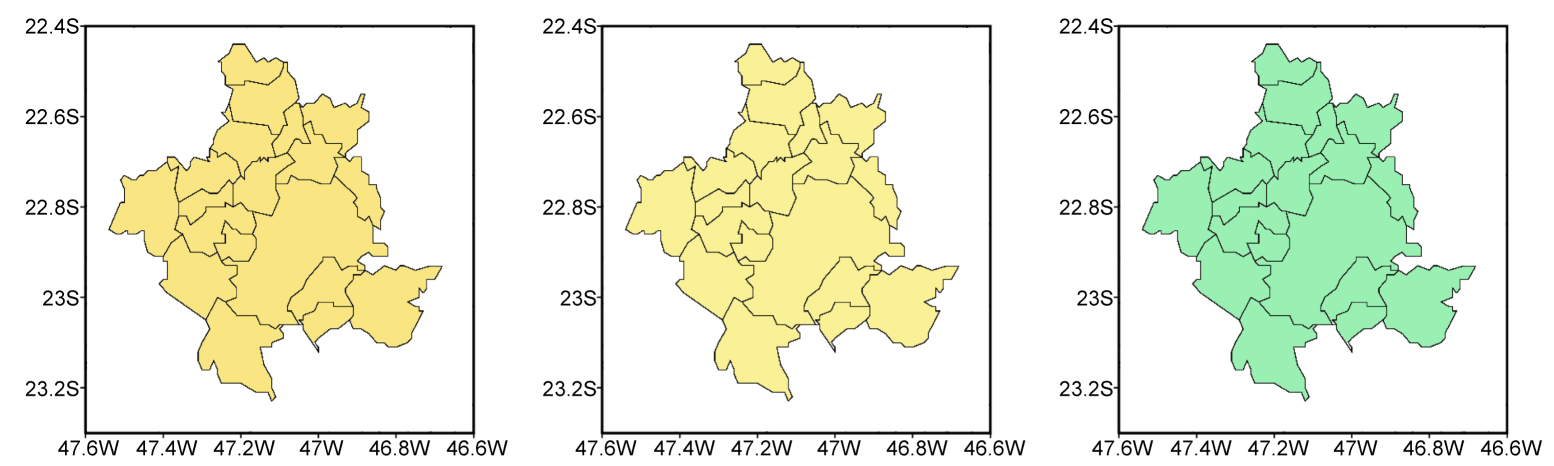

(a) SON (2011-2040) - (1961-1990) MRC
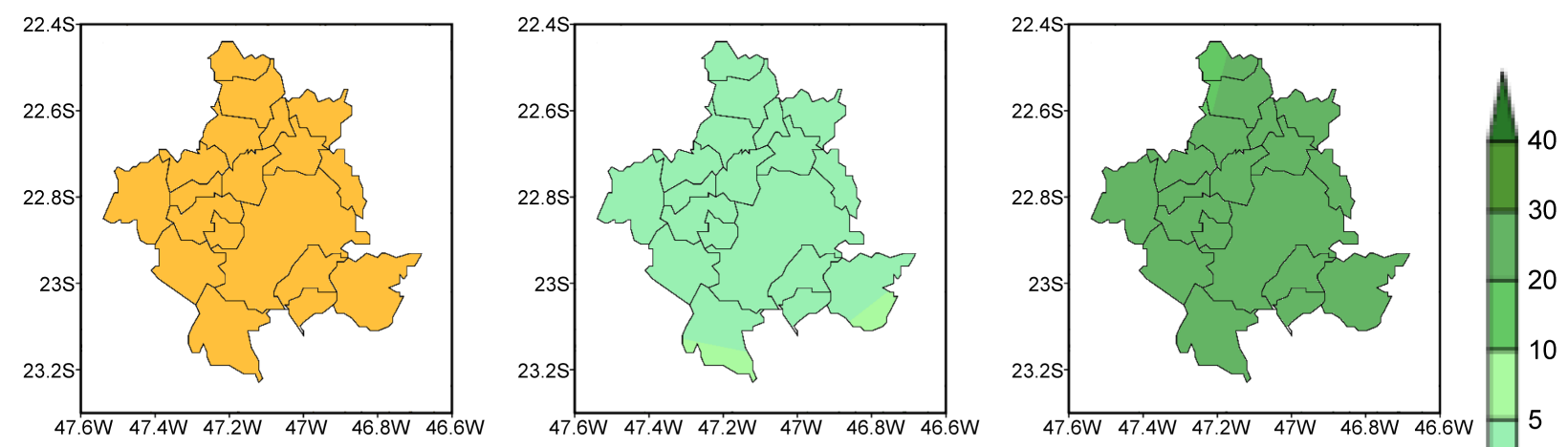

(b) SON (2070-2099) - (1961-1990) MRC
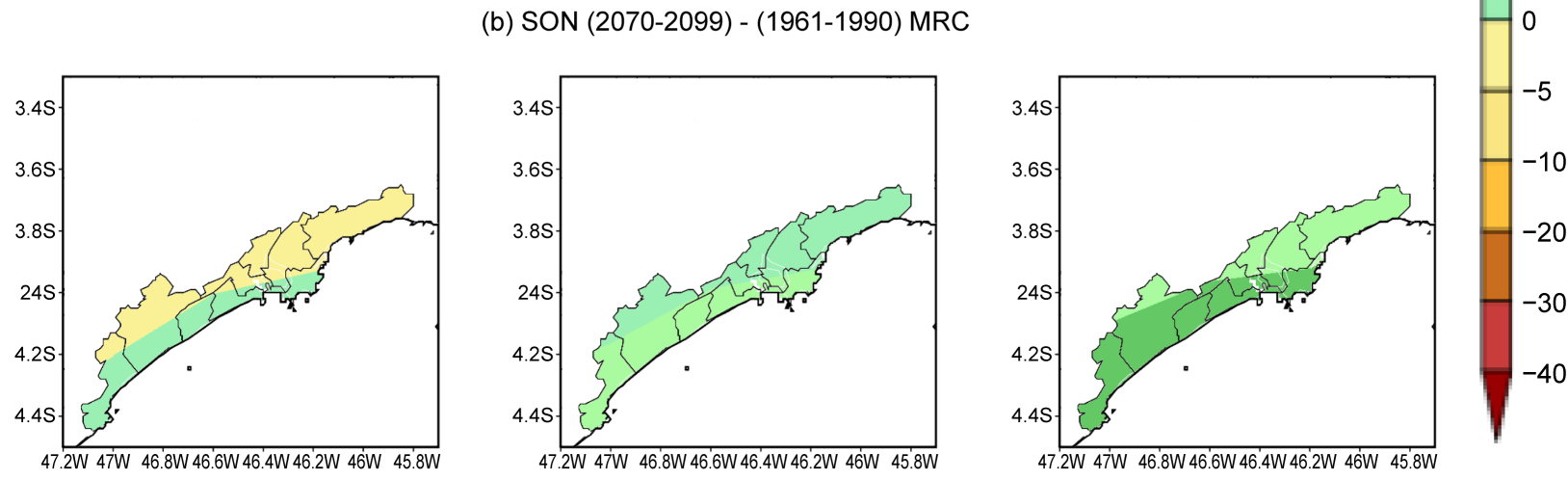

(c) SON (2011-2040) - (1961-1990) MRBS
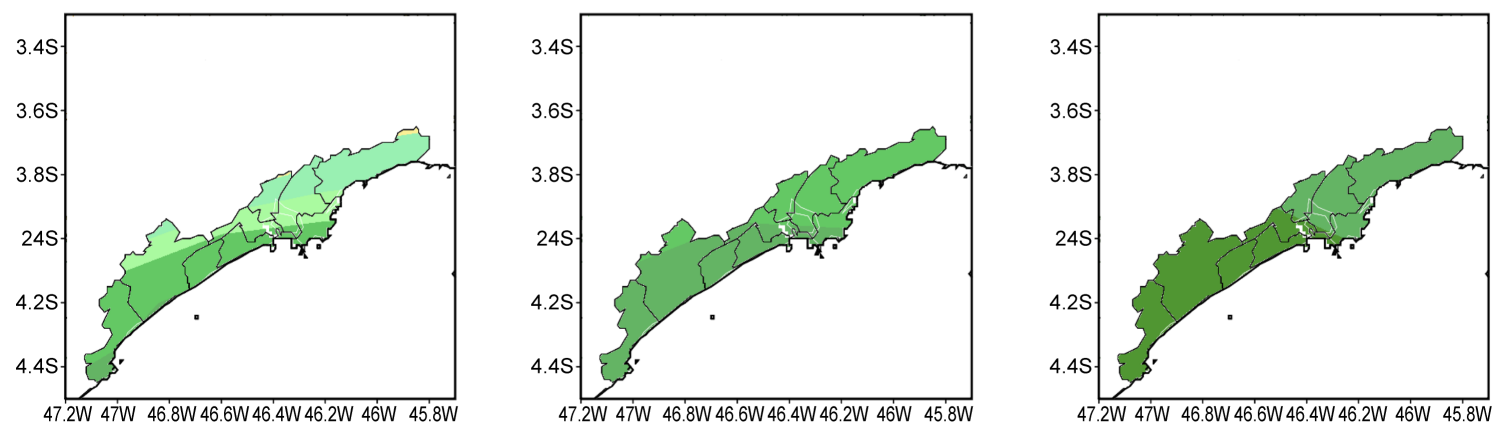

(d) SON (2070-2099) - (1961-1990) MRBS

Figure 8. Difference of precipitation in SON between future projections and the base period in \% for the ensemble minus standard deviation among members (left panel), ensemble (middle panel) and ensemble plus standard deviation among members (right panel). (a) (2011-2040) - (1961-1990) at MRC, (b) (2070-2099) - (1961-1990) at MRC, (c) (2011-2040) - (1961-1990) at MRBS, (d) (2070-2099) - (1961-1990) at MRBS. 
DJF

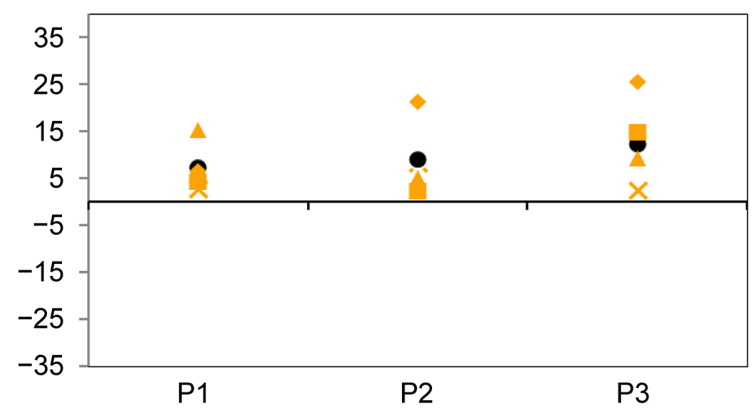

JJA

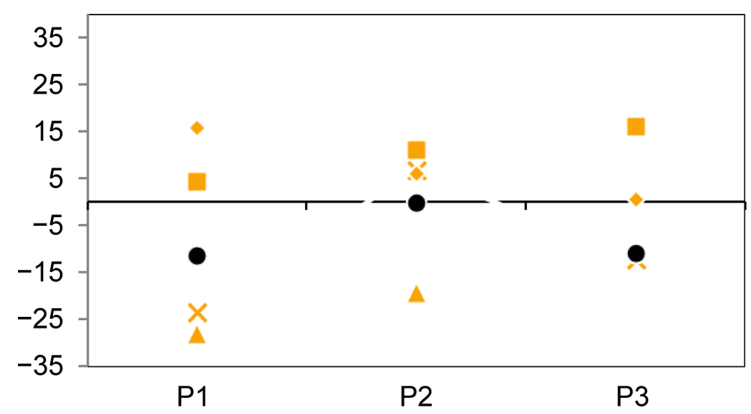

DJF

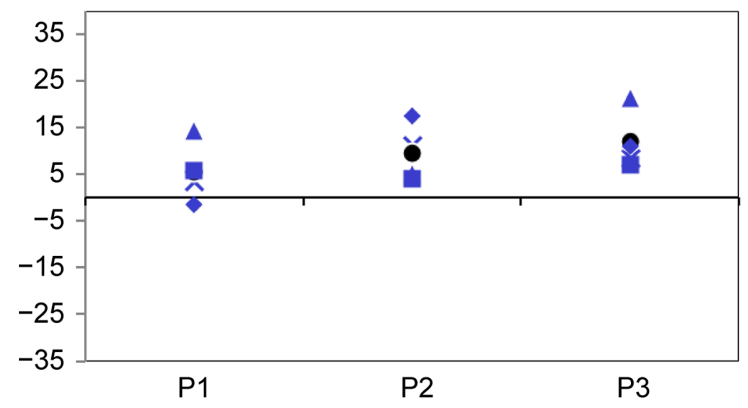

JJA

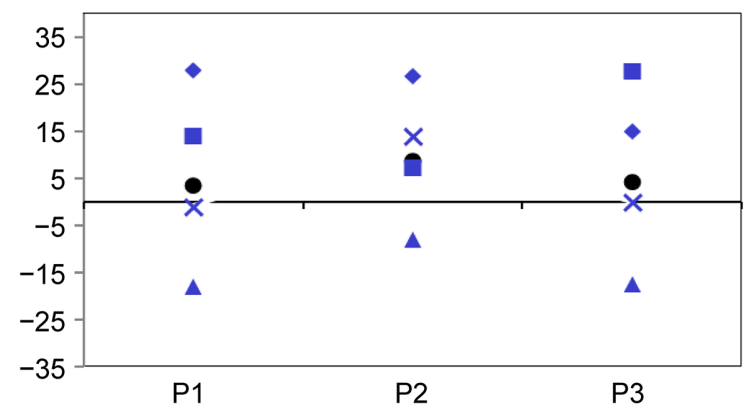

MAM

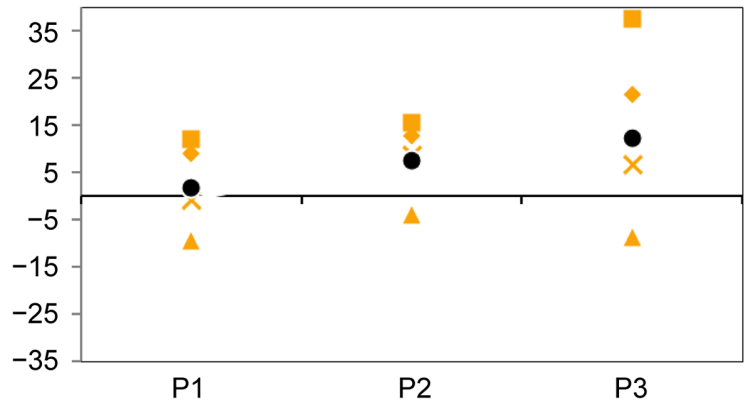

SON

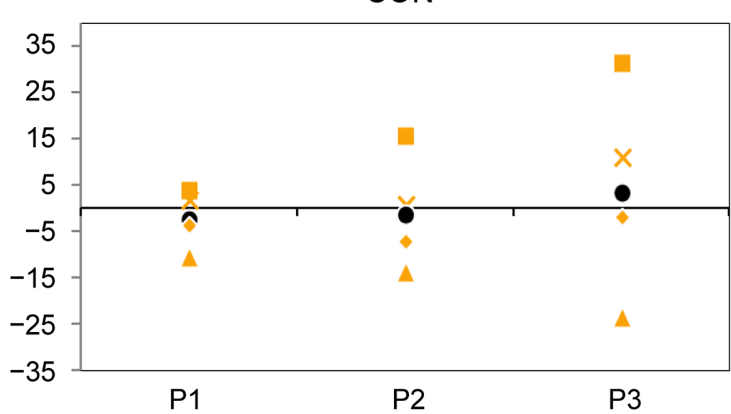

(a)

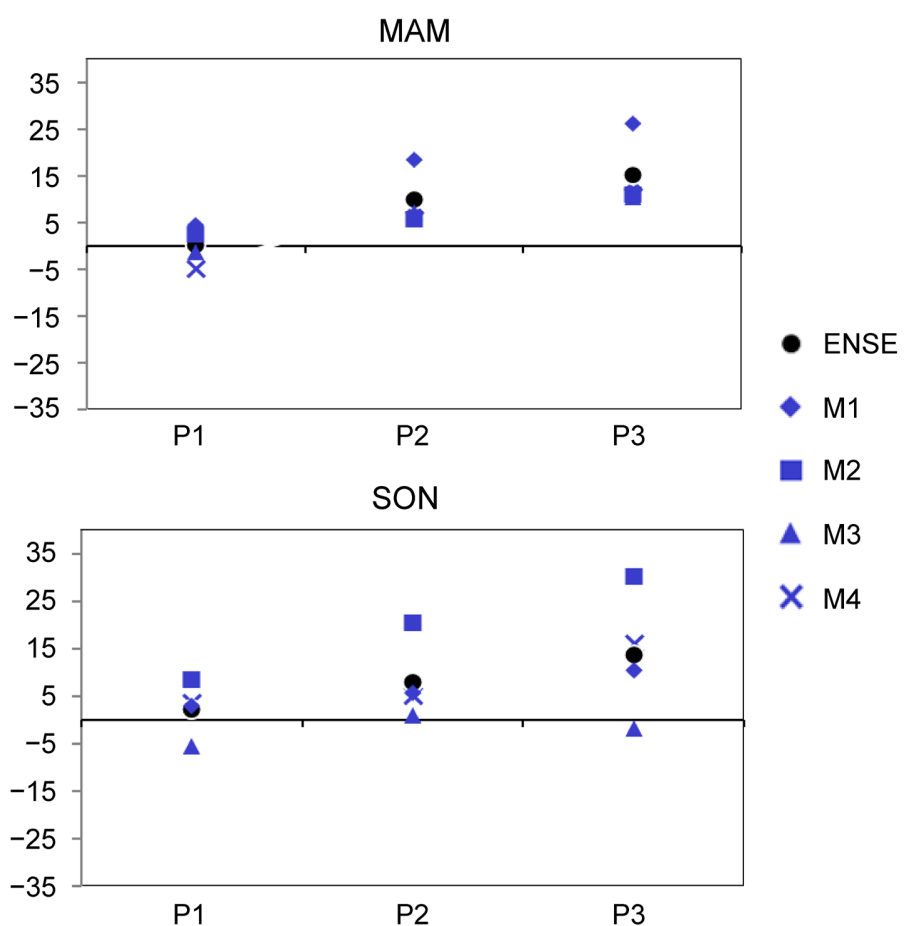

(b)
ENSE

M1

M2

4. M3

$\times \quad M 4$
ENSE

Figure 9. Precipitation difference between future projections and base period. (a) MRC, (b) MRBS. P1: (2011-2040) - (1961-1990), P2: (2041-2070) - (1961-1990), P3: (2070-2099) - (1961-1990).

(Figure 6(b)). At MRBS the interval is between $-5 \%$ to $10 \%$ (Figure 6(c)) during (2011-2040) and the uncertainties reduce during (2070-2099) as the changes show increase between $10 \%$ and 30\% (Figure 6(d)). The spread in Figure 9 
shows precipitation increase in the majority of members in both locations. JJA (2011-2040) and (2070-2099) present the larger uncertainties regarding the standard deviation among the members in both regions (Figure 7). The ensemble minus the standard deviation shows reduced precipitation in both locations and the ensemble plus the standard deviation shows increased precipitation. The interval ranges from $-40 \%$ to $10 \%$ in MRC and from $-20 \%$ to $30 \%$ in MRBS during (2011-2040). During (2070-2099) the intervals change from $-40 \%$ to $20 \%$ in MRC and from $-10 \%$ to $30 \%$ in MRBS. The uncertainties are also seen in the spread (Figure 9), although the ensemble shows reduction during two future periods in MRC and increase during three future periods in MRBS. In SON, MRC displays changes between $-10 \%$ and $5 \%$ and MRBS changes between $-5 \%$ and 20\% during (2011-2040) (Figure 8(a), Figure 8(c)). The interval of changes increases in (2070-2099) from $-20 \%$ to $30 \%$ in MRC and between $0 \%$ and $40 \%$ in MRBS (Figure 8(b), Figure 8(d)). Therefore the uncertainties in SON are larger in MRC than in MRBS, which is also seen in Figure 9 that shows precipitation increase in MRBS projected by the ensemble and the majority of members, while in MRC there is large spread among the members.

\section{Precipitation Indices}

The indices of Table 1 are shown in Figure 10(a) and Figure 10(b) for MRC and MRBS, respectively. SDII and SDII10 are well represented by the model, while R1 and R10 are overestimated in MRC. In this location, the projections show a gradual increase in the mean precipitation above $1 \mathrm{~mm}$ (SDII) and 10 $\mathrm{mm}$ (SDII10) from the base period (1961-1990) to the last period of $21^{\text {st }}$ century (2071-2098), with low spread among the members, represented by the minimum and maximum values. The number of rainy days (R1) reduces along the period, while there are small changes in the number of days with heavier precipitation (R10). The concurrent reduction of rainy days and precipitation increase, in the future, indicate more intense rains concentrated in a few days. In MRBS the model underestimates the four indices, but there is also an increase of SDII and SDII10 and reduction of R1.

The changes in the distributions of rain intensity are presented in Figure 11 (MRC) and Figure 12 (MRBS). In MRC there is an increase of days without rain in two future periods (2011-2040) and (2041-2070), but in (2071-2100) the uncertainty is high, since there are two members with opposite changes. There are less days with light rains in the three future periods, and the reduction is larger in the last period. The number of heavy rain increases, mainly in the last two periods (Figure 11(b)). In MRBS (Figure 12) the behavior of the days without rain is similar, with increase of dry days in the first two future periods and more uncertainty in the last. There is also a reduction of days with light rains and increase of heavy rains in the future projections. This result is consistent with other studies over South America that show an increase in the frequency of daily precipitation extremes in future periods [6] [24] [34]. 

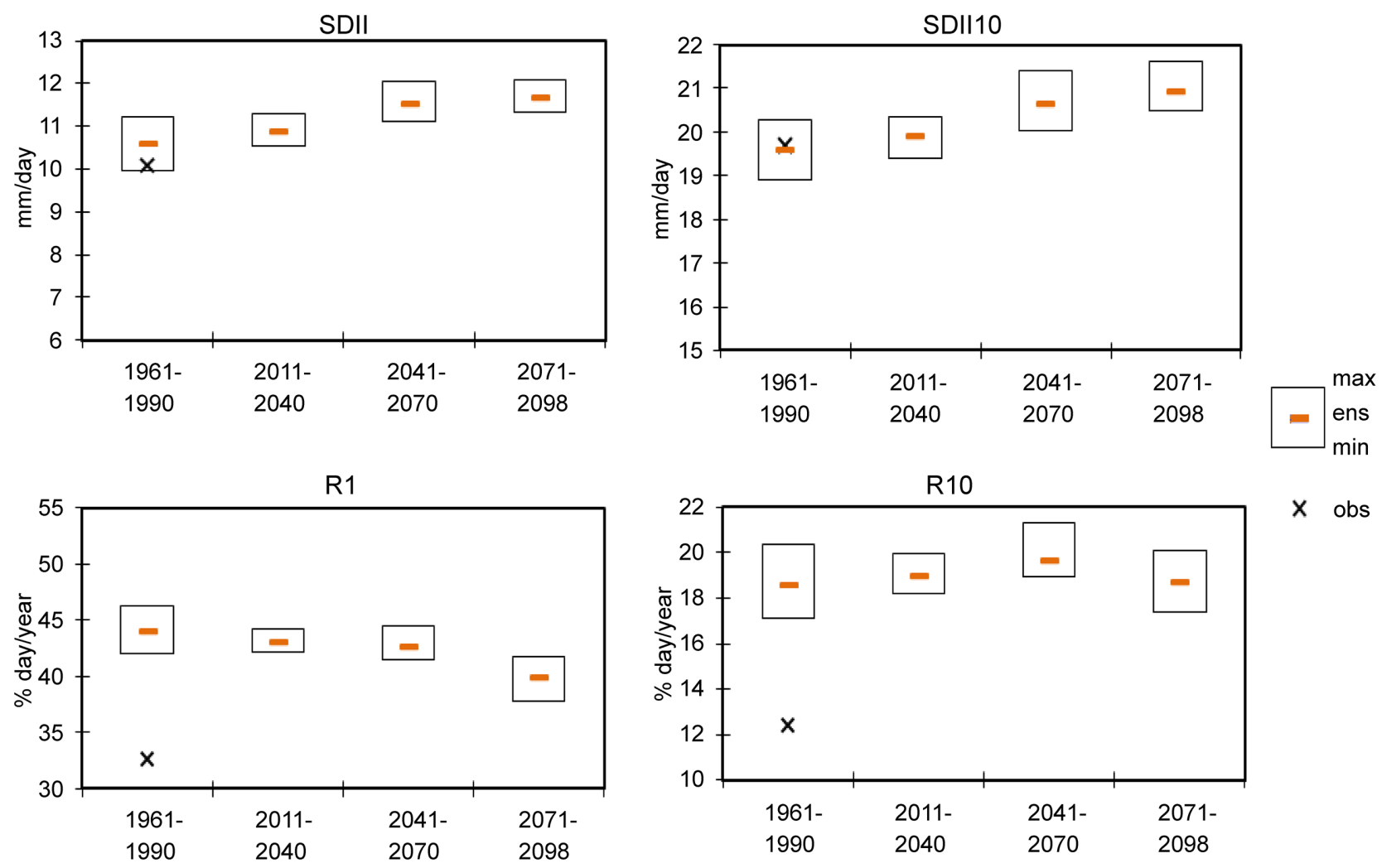

$x$ obs

(a)
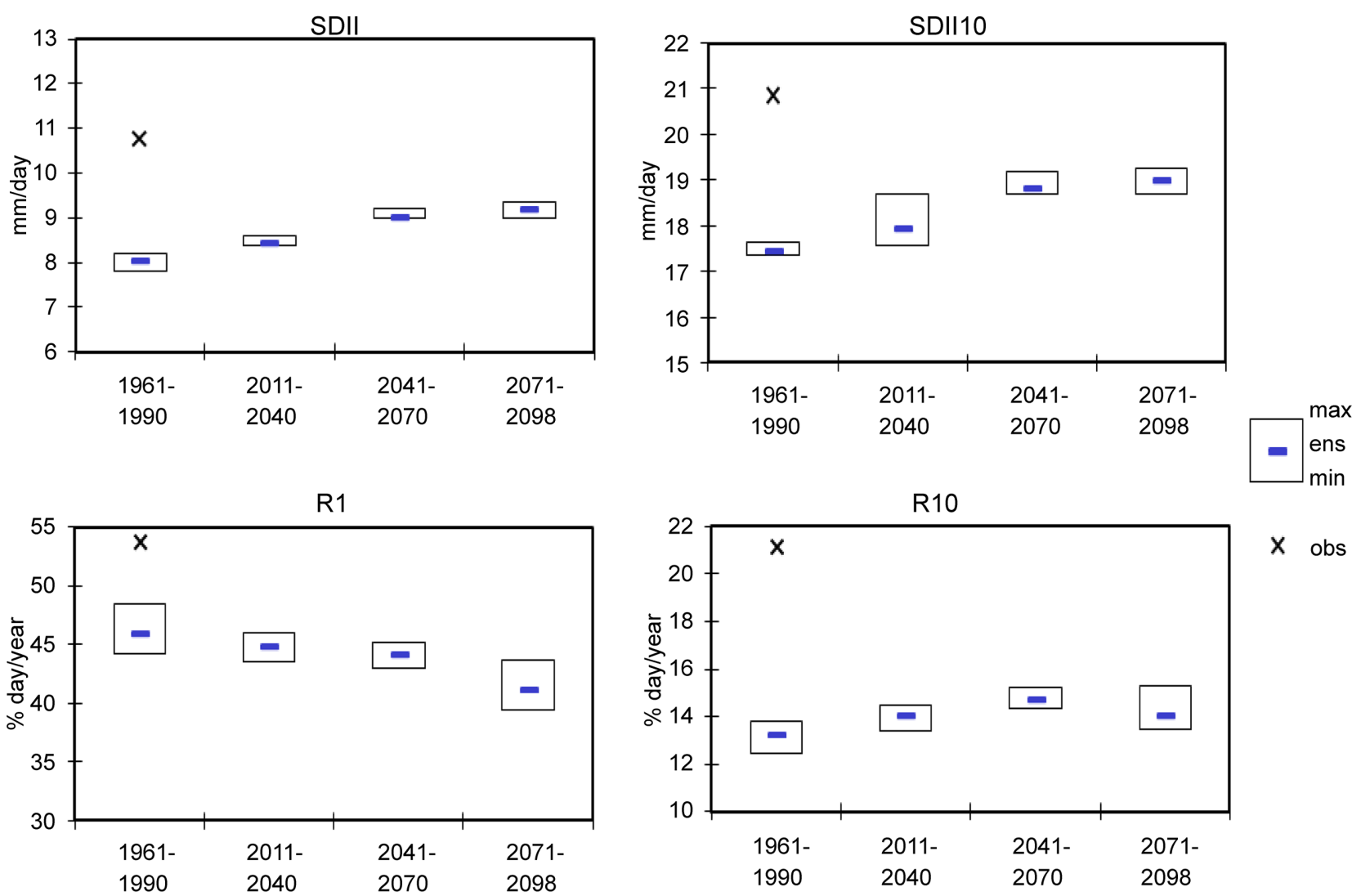

(b)

Figure 10. Precipitation indices of SDII, SDII10, R1 and R10. (a) MRC, (b) MRBS. 

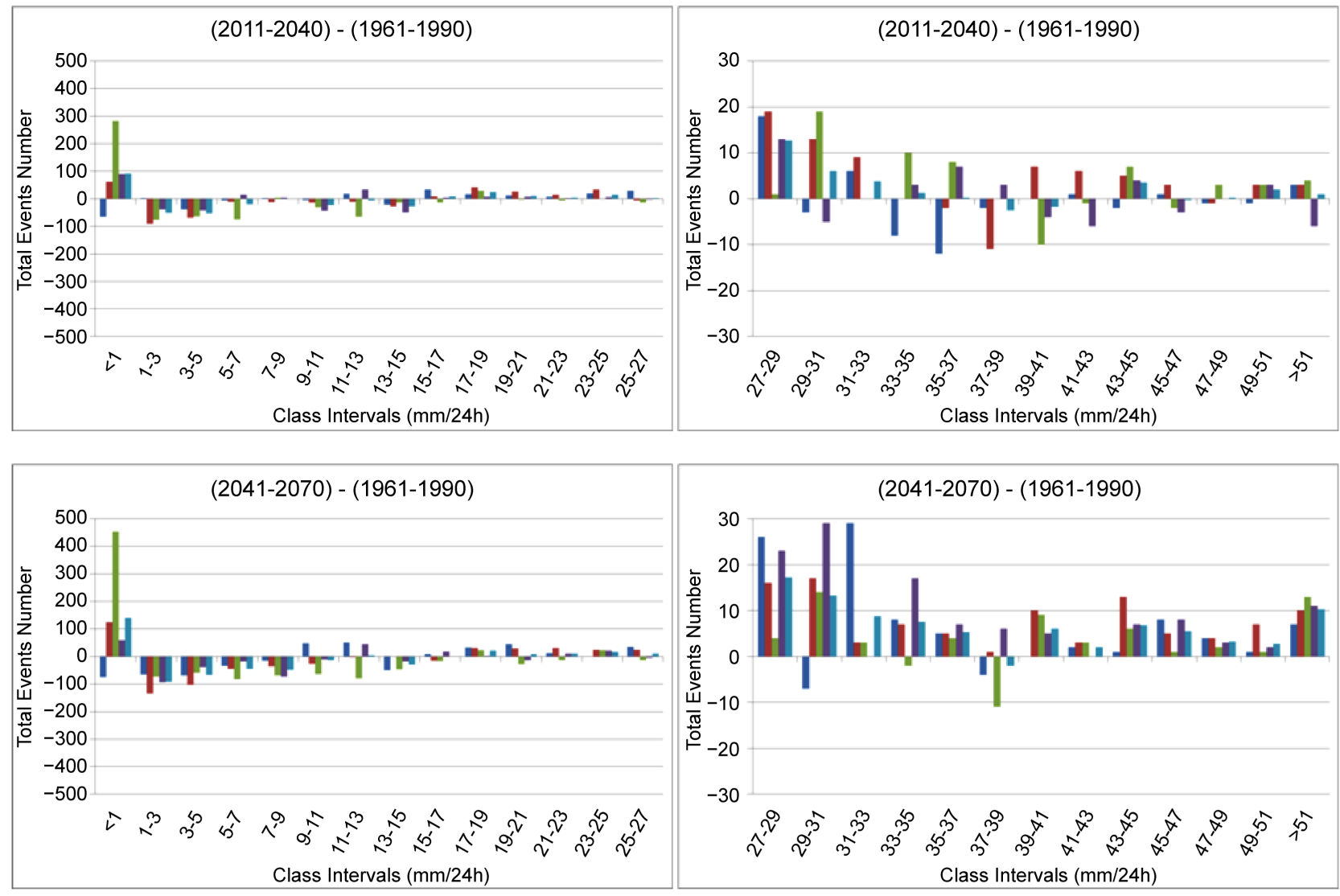

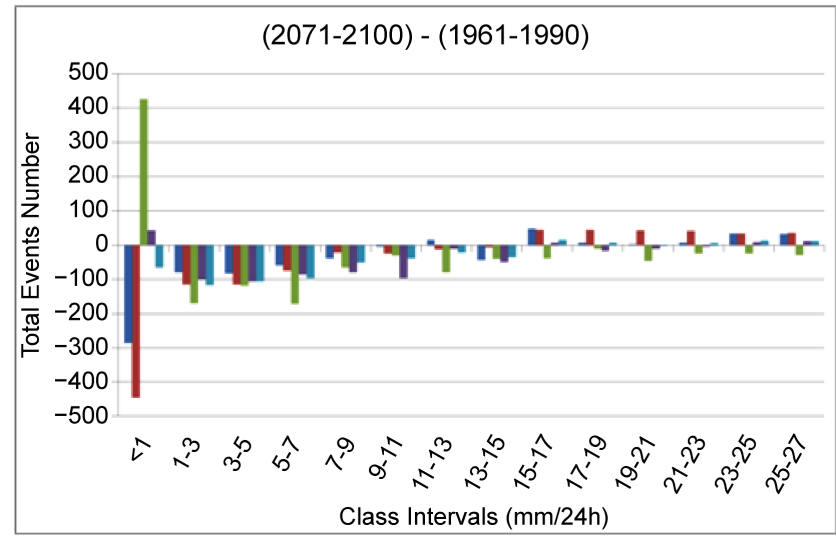

(a)

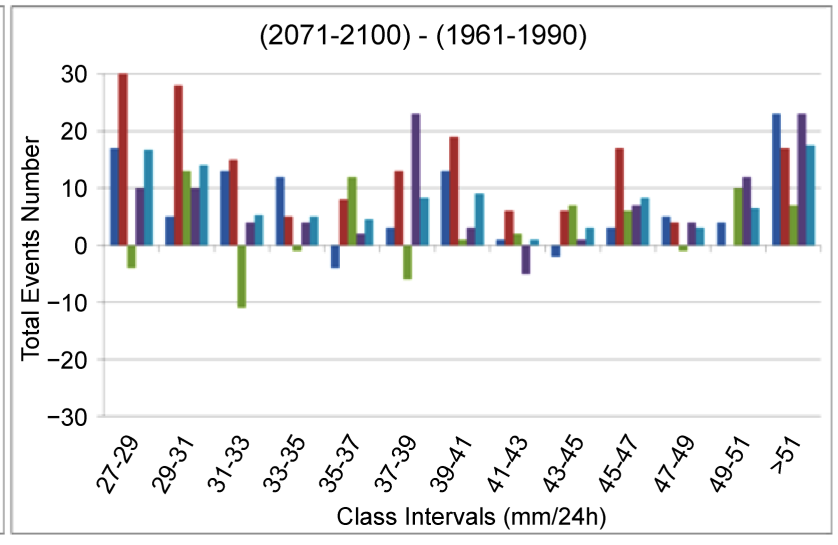

(b)

Figure 11. Frequency distribution of precipitation events in MRC. (a) Precipitation $<1-27 \mathrm{~mm} /$ day, (b) Precipitation between 27 and $>51 \mathrm{~mm} /$ day.

\section{Patterns of Extreme Monthly Precipitation}

Besides the heavy daily precipitation, which can cause damages in the two metropolitan regions, as discussed in session 3, monthly extremes are also important to agriculture and water resources. These are calculated from the Standard Precipitation Index (SPI), which identifies extreme, severe and moderate monthly events. As the SPI is calculated from anomalies relative to the climatology of each period, the results do not show a systematic change in the frequency of extreme, severe and moderate cases from the base to the future periods. 

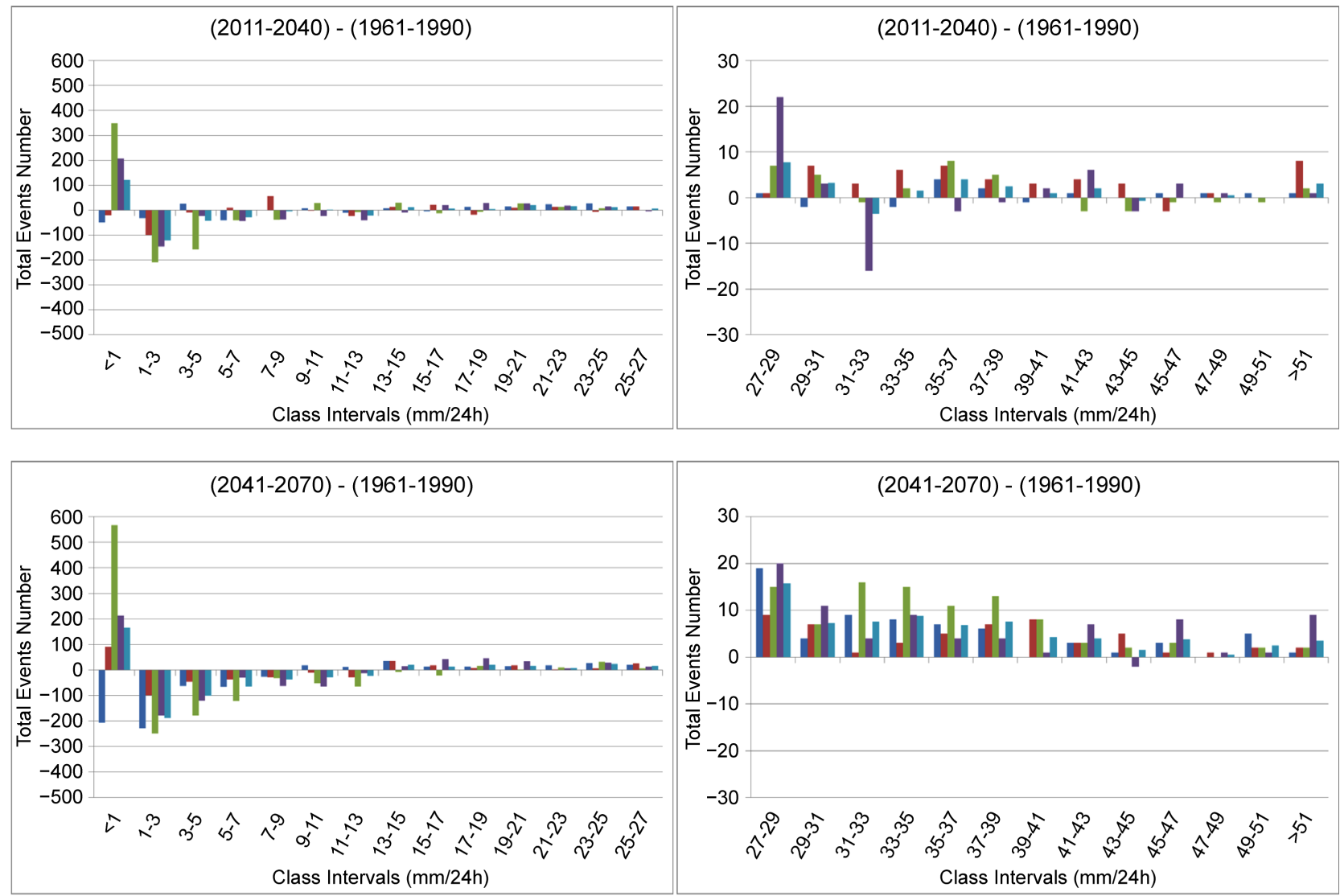

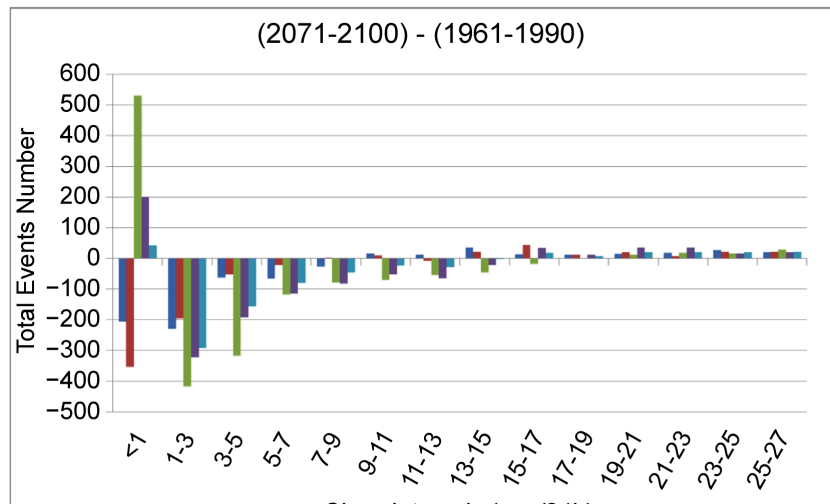

Class Intervals $(\mathrm{mm} / 24 \mathrm{~h})$

(a)

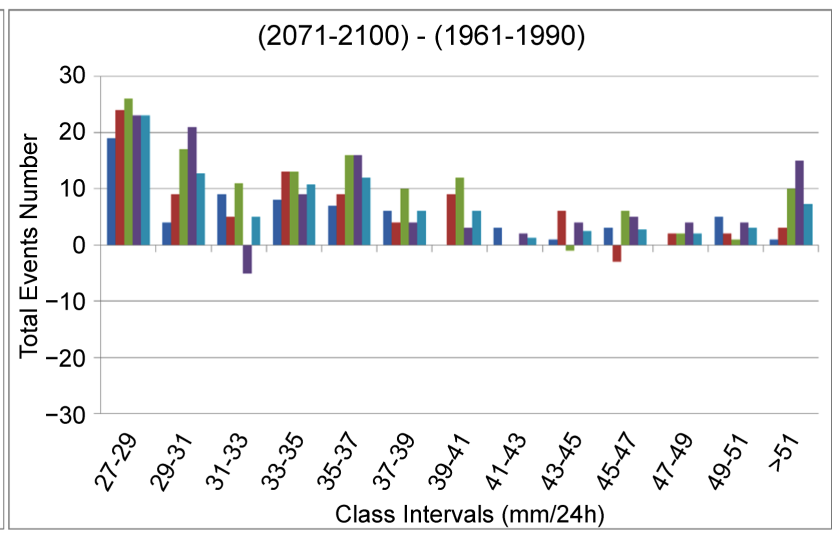

(b)

Figure 12. Frequency distribution of precipitation events in MRBS. (a) Precipitation $<1-27 \mathrm{~mm} /$ day, (b) Precipitation between 27 and $>51 \mathrm{~mm} /$ day.

In order to see what is the simulated precipitation pattern related to the extremes in the two locations, seasonal composites from extreme wet monthly events during the base period were analyzed. Composites for each region showed similar patterns; therefore we show the composites regarding the selected cases of precipitation extremes in both regions of MRC and MRBS (Figure 13). In DJF the pattern resembles the dipole associated with the SACZ variability [11] [18] [19] [35] and indicates, in this case, the weakness or southward displacement of the SACZ (Figure 13(a)). Previous studies show that this dipole is related to the 


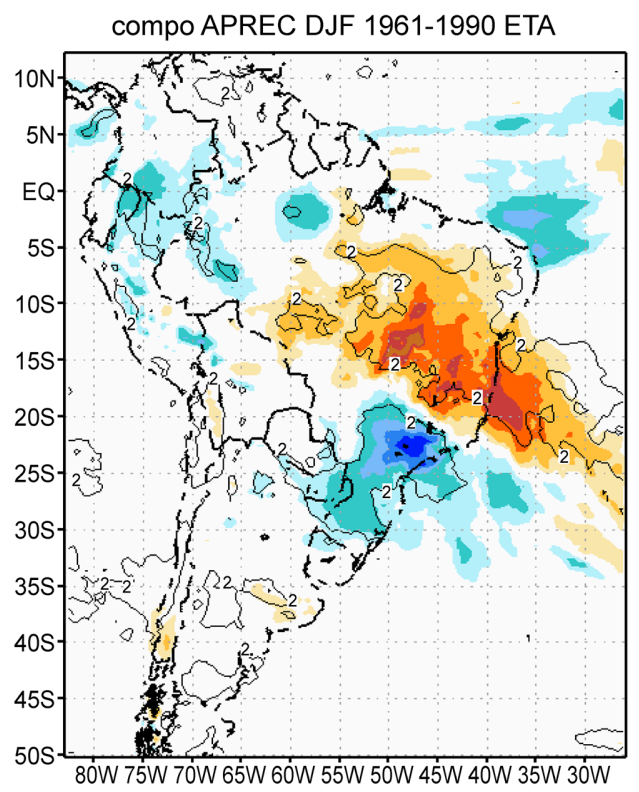

(a)

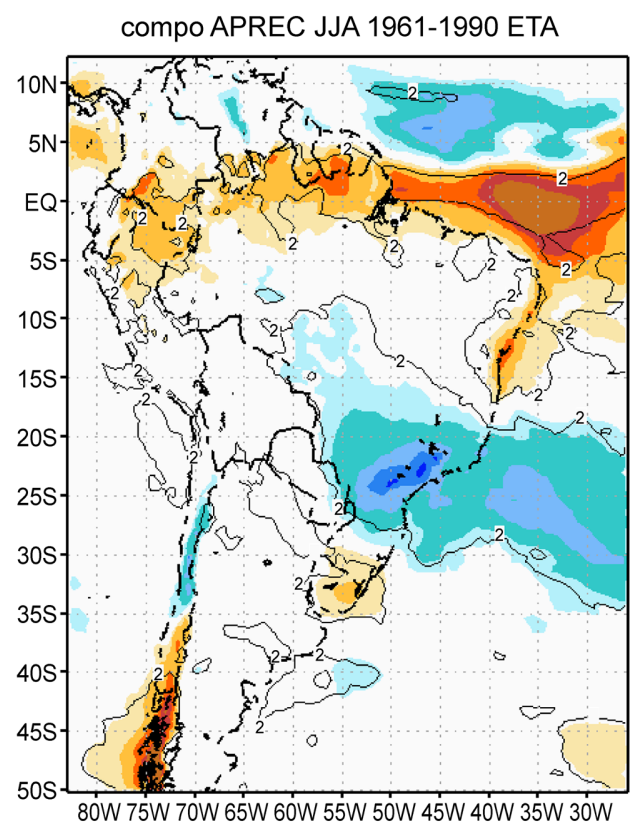

(c)
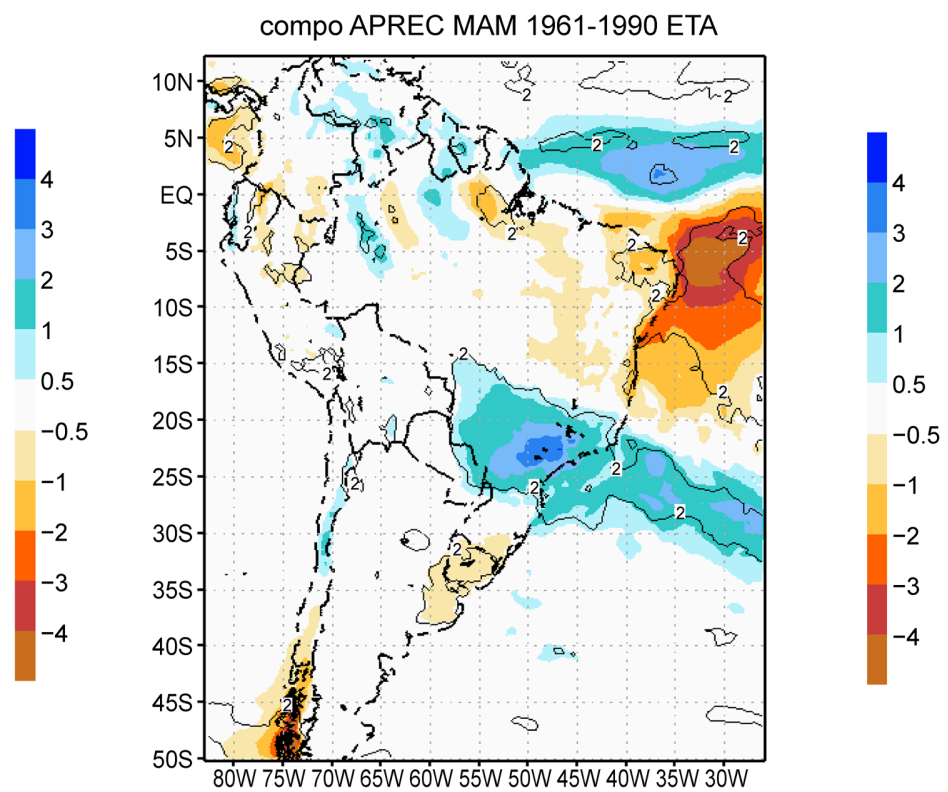

(b)
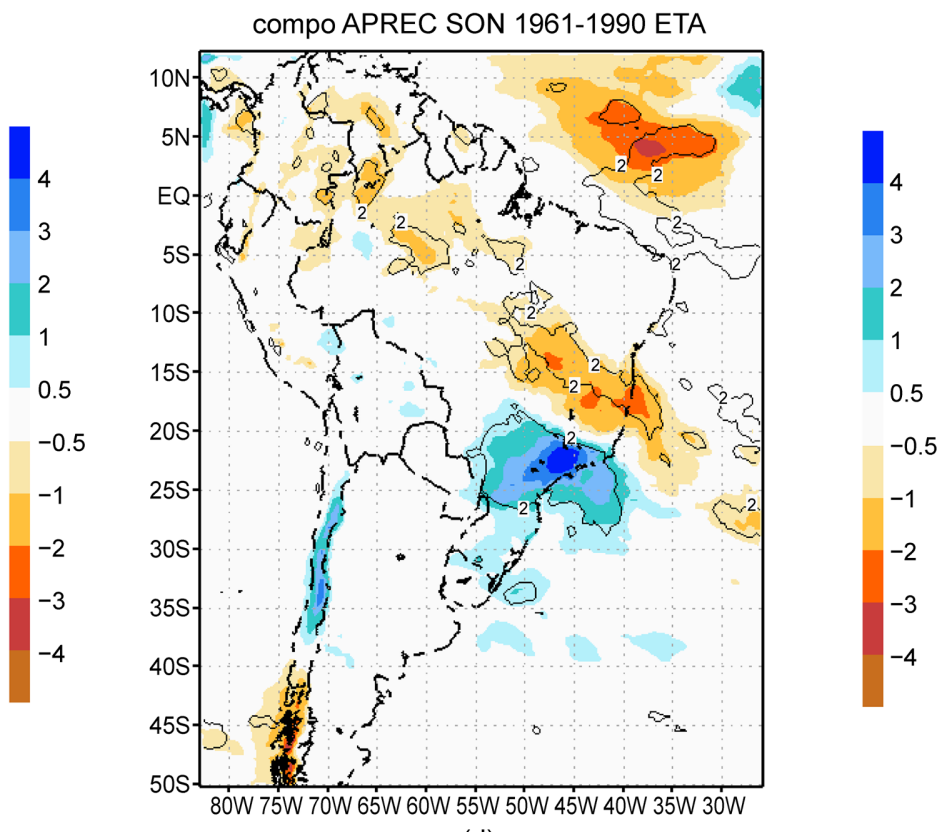

(d)

Figure 13. Composites of extreme wet monthly precipitation in MRC and MRBS in each season (mm/day) simulated by the Eta model during 1961-1990. The contour lines indicate regions with significance greater than 95\%.

Pacific South America (PSA) wave-train pattern [10] [19] [35] and humidity flux from the Amazon region [36]. In MAM the pattern may show the influence of frequent or/and persistent frontal systems. Dry conditions to the north, mainly related to the ITCZ displaced northwards may indicate a large scale subsidence which traps the frontal systems over part of southeast and south regions (Figure 13(b)). In JJA the pattern indicates again the presence of frontal systems and dry conditions in the tropical region (Figure 13(c)). The precipitation dipole returns in SON, season that marks the beginning of the rainy season in the South Amer- 
ica Monsoon region [37] [38] [39], although weaker than in DJF (Figure 13(d)).

It is also noted a precipitation dipole over Chile, which indicates the displacement of synoptic systems northward of the normal track. Therefore, the regional ETA model represents well the patterns associated with extreme monthly precipitation in the two regions of southeastern Brazil. It identifies the pattern of frontal systems, in MAM and JJA, and the influence of the SACZ in DJF and SON. The impact of these systems on observed extreme precipitation over Southeastern Brazil have been discussed in several studies, such as [9] [11] [22]. The ability of the ETA model in identifying seasonal patterns of extreme precipitation related to the influence of observed systems can increase the confidence on model results, reducing uncertainties, and also can be useful for seasonal predictions.

\section{Conclusions}

The two metropolitan regions (MRC and MRBS) are vulnerable in face of climate change. The model underestimates precipitation in MRBS, but represents well the annual precipitation cycle in MRC, although with overestimated values. In MRC, the projections in the near and distant future periods show precipitation increase during DJF, while there are more uncertainties in the other seasons. In MRBS, precipitation increase is projected during DJF, MAM and SON of the last period of the $21^{\text {st }}$ century. The uncertainties are larger in JJA in both locations. The ensemble mean shows increased precipitation from late spring to middle summer and reduced precipitation from middle winter to early spring months, indicating drier conditions in the dry season and wetter conditions in the rainy season. The increase in the summer season and the decrease in the spring are consistent with [40] which discusses the delay in the South American Monsoon System due to drier conditions in this later season in future projections. In MRBS, the reduction from middle winter to early spring is very small, likely due to the location close to the sea. The projections show a precipitation increase during the rainy days and a reduction of the rainy days' number in both areas, indicating intensity increase in future projections.

The changes may impact the economy and may increase social problems due to floods and droughts in MRC and floods and landslides in MRBS. The vulnerabilities and the impacts of climate change need to be considered in adaptation actions in both regions. Even disregarding the effects of climate change, adaptation to the existing level of changes in both study areas is already critical. Due to the rapid transformation of these lively metropolitan regions, which place population at greater risk for natural disasters, including those expected to worsen with climate change, new challenges are posed, among them to understand and respond to the complex interactions between urban development and the climate system in view of building more resilient and adapted cities.

\section{Acknowledgements}

To IVA-FAPESP Project (Proc. 08/58161-1), FAPESP-Belmont Grant 2012/ 
51876-0 and FAPESP RCUK PULSE Grant 2011/51843-2. I. F. A. C. and J. A. M. are grateful also to $\mathrm{CNPq}$ for research support.

\section{References}

[1] Vincent, K. (2007) Uncertainty in Adaptive Capacity and the Importance of Scale. Global Environmental Change, 17, 12-24.

[2] IPCC (2012) Managing the Risks of Extreme Events and Disasters to Advance Climate Change Adaptation. In: Field, C.B., Barros, V., Stocker, T.F., Qin, D., Dokken, D.J., Ebi, K.L., Mastrandrea, M.D., Mach, K.J., Plattner, G.-K., Allen, S.K., Tignor, M. and Midgley, P.M., Eds., A Special Report of Working Groups I and II of the Intergovernmental Panel on Climate Change Field, Cambridge University Press, Cambridge and New York, $582 \mathrm{p}$.

[3] Turner, B.L., Kaspersonb, R.E., Matsone, P.A., McCarthyf, J.J., Corellg, R.W., Christensene, L., Eckleygh, N., Kasperson, J.X., Luerse, A., Martellog, M.L., Polsky, C., Pulsiphera, A. and Schiller, A. (2003) A Framework for Vulnerability Analysis in Sustainability Science. Proceedings of the National Academy of Sciences of the United States of America, 100, 8074-8079. https://doi.org/10.1073/pnas.1231335100

[4] Liebmann, B., Jones, C. and Carvalho, L.M.V. (2001) Interannual Variability of Daily Extreme Precipitation Events in the State of São Paulo, Brazil. Journal of Climate, 14, 208-218. https://doi.org/10.1175/1520-0442(2001)014<0208:IVODEP > 2.0.CO;2

[5] Carvalho, L.M.V., Jones, C. and Liebmann, B. (2002) Extreme Precipitation Events in Southeastern South America and Large-Scale Convective Patterns in the South Atlantic Convergence Zone. Journal of Climate, 15, 2377-2394. https://doi.org/10.1175/1520-0442(2002)015<2377:EPEISS>2.0.CO;2

[6] Marengo, J.A., Valverde, M.C. and Obregón, G.O. (2013) Observed and Projected Changes in Rainfall Extremes in the Metropolitan Area of São Paulo. Climate Research, 57, 61-72. https://doi.org/10.3354/cr01160

[7] Silva Dias, M.A.F., Dias, J., Carvalho, L.M.V., Freitas, E.D. and Silva Dias, P.L. (2013) Changes in Extreme Dailyrainfall for São Paulo, Brazil. Climatic Change, 116, 705-722. https://doi.org/10.1007/s10584-012-0504-7

[8] Obregón, G.O., Marengo, J.A. and Nobre, C.A. (2014) Rainfall and Climate Variability: Long-Term Trends in the Metropolitan Area of São Paulo in the 20th Century. Climate Research, 61, 93-107. https://doi.org/10.3354/cr01241

[9] Lima, K., Satyamurti, P. and Fernandez, J.P.R. (2010) Large-Scale Atmospheric Conditions Associated with Heavy Rainfall Episodes in Southeast Brazil. Theoretical Applied Climatology, 101, 121-135. https://doi.org/10.1007/s00704-009-0207-9

[10] Vasconcellos, F.C. and Cavalcanti, I.F.A. (2010) Extreme Precipitation over Southeastern Brazil in the Austral Summer and Relations with the Southern Hemisphere Annular Mode. Atmospheric Science Letters, 11, 21-26.

https://doi.org/10.1002/asl.247

[11] Carvalho, L.M.V., Jones, C. and Liebmann, B. (2004) The South Atlantic Convergence Zone: Intensity, Form, Persistence, and Relationships with Intraseasonal to Interannual Activity and Extreme Rainfall. Journal of Climate, 17, 88-108. https://doi.org/10.1175/1520-0442(2004)017<0088:TSACZI >2.0.CO;2

[12] Rusticucci, M., Marengo, J., Penalba, O. and Renom, M. (2010) An Intercomparison of Model-Simulated in Extreme Rainfall and Temperature Events during the Last Half of the XX Century: Part 1: Mean Values and Variability. Climatic Change, 98, 509-529. https://doi.org/10.1007/s10584-009-9742-8

[13] Marengo, J.A., Rusticucci, M., Penalba, O. and Renom, M. (2010) An Intercompa- 
rison of Observed and Simulated Extreme Rainfall and Temperature Events during the Last Half of the Twentieth Century: Part 2: Historical Trends. Climatic Change, 98, 509-529. https://doi.org/10.1007/s10584-009-9743-7

[14] Solman, S.A. and Pessacg, N.L. (2012) Evaluating Uncertainties in Regional Climate Simulations over South America at the Seasonal Scale. Climate Dynamics, 39, 59-76. https://doi.org/10.1007/s00382-011-1219-6

[15] Blazquez, J. and Nunez, M.N. (2013) Analysis of Uncertainties in Future Climate Projections for South America: Comparison of WCRP-CMIP3 and WCRP-CMIP5 Models. Climate Dynamics, 41, 1039-1056. https://doi.org/10.1007/s00382-012-1489-7

[16] Torres, R.R. and Marengo, J.A. (2013) Uncertainty Assessments of Climate Change Projections over South America. Theoretical Applied Climatology, 112, 253-272. https://doi.org/10.1007/s00704-012-0718-7

[17] Kodama, Y. (1992) Large Scale Common Features of Subtropical Precipitation Zones (The Baiu Frontal Zone, the SPCZ, and the SACZ) Part I: Characteristics of Subtropical Frontal Zones. Journal of Meteorological Society of Japan, 70, 813-836.

[18] Liebmann, B., Kiladis, G.N., Marengo, J.A., Ambrizzi, T. and Glick, J.D. (1999) Submonthly Convective Variability over South America and the South Atlantic Convergence Zone. Journal of Climate, 12, 1877-1891. https://doi.org/10.1175/1520-0442(1999)012<1877:SCVOSA $>2.0 . C O ; 2$

[19] Cunningham, C.A.C. and Cavalcanti, I.F.A. (2006) Intraseasonal Modes of Variability Affecting the South Atlantic Convergence Zone. International Journal of Climatology, 26, 1165-1180. https://doi.org/10.1002/joc.1309

[20] Drumond, A., Marengo, J.A., Ambrizzi, T., Nieto, R., Moreira, L. and Gimeno, L. (2014) The Role of the Amazon Basin Moisture in the Atmospheric Branch of the Hydrological Cycle: A Lagrangian Analysis. Hydrology and Earth System Science, 18, 2577-2598. https://doi.org/10.5194/hess-18-2577-2014

[21] Cavalcanti, I.F.A. (2012) Large Scale and Synoptic Features Associated with Extreme Precipitation over South America: A Review and Case Studies for the First Decade of the 21st Century. Atmospheric Research, 118, 27-40.

[22] Chou, S.C., Marengo, J.A., Lyra, A.A., Sueiro, G., Pesquero, J.F., Alves, L.M., Kay, G., Betts, R., Chagas, D.J., Gomes, J.L., Bustamante, J.F. and Tavares, P. (2012) Downscaling of South America Present Climate Driven by 4-Member HadCM3 Runs. Climate Dynamics, 38, 635-653. https://doi.org/10.1007/s00382-011-1002-8

[23] Chou, S.C., Lyra, A., Mourão, C., Dereczynski, C., Pilotto, I., Gomes, J.L., Bustamante, J., Tavares, P., Silva, A., Rodrigues, D., Campos, D., Chagas, D., Sueiro, G., Siqueira, G., Nobre, P. and Marengo, J.A. (2014) Evaluation of the Eta Simulations Nested in Three Global ClimateModels. American Journal of Climate Change, 3, 438-454. https://doi.org/10.4236/ajcc.2014.35039

[24] Chou, S.C., Lyra, A., Mourão, C., Dereczynski, C., Pilotto, I., Gomes, J.L., Bustamante, J., Tavares, P., Silva, A., Rodrigues, D., Campos, D., Chagas, D., Sueiro, G., Siqueira, G. and Marengo, J.A. (2014) Assessment of Climate Change over South America under RCP 4.5 and 8.5 Downscaling Scenarios. American Journal of Climate Change, 3, 512-527. https://doi.org/10.4236/ajcc.2014.35043

[25] Marengo, J.A., Chou, S.C., Kay, G., Alves, L.M., Pesquero, J.F., Soares, W.R., Santos, D.C., Lyra, A., Sueiro, G., Betts, R., Chagas, D.J., Gomes, J.L., Bustamante, J.F. and Tavares, P. (2012) Development of Regional Future Climate Change Scenarios in South America Using the Eta CPTEC/HadCM3 Climate Change Projections: Climatology and Regional Analyses for the Amazon, São Francisco and the Parana River Basins. Climate Dynamics, 38, 1829-1848. 
https://doi.org/10.1007/s00382-011-1155-5

[26] Collins, M., Tett, S.F.B. and Cooper, C. (2001) The Internal Climate Variability of a HadCM3, a Version of the Hadley Centre Coupled Model without Flux Adjustments. Climate Dynamics, 17, 61-81. https://doi.org/10.1007/s003820000094

[27] IPEA (2015) Atlas da Vulnerabilidade Social nos municípios brasileiros. http://ivs.ipea.gov.br/ivs/

[28] Castellano, M.S. and Nunes, L.H. (2011) Extreme Precipitation Events and Their Socio-Spatial Impacts on a Brazilian Urban Center: Campinas-SP. 6th European Conference on Severe Storms, 3-7 October 2011, Palma de Mallorca.

[29] Vicente, A.K. and Nunes, L.H. (2004) Extreme Precipitation Events in Campinas, Brazil. Terræ Geosciences Geography and the Environment, 1, 60-63.

[30] Nunes, L.H. and Fernandes, S.F. (2013) Impacts of Precipitation Episodes in Campinas, Brazil. UNISDR Scientific, Technical and Advisory Group Case Studies. http://www.preventionweb.net/files/workspace/7935_nunesandfernandes.pdf

[31] Martín-Vide, J. (2004) Spatial Distribution of Daily Precipitation Concentration Index in Peninsular Spain. International Journal of Climatology, 24, 959-971. https://doi.org/10.1002/joc.1030

[32] Nunes, L.H., Martín-Vide, J. and Gabriel, G.H. (2013) Intense Precipitation Pattern by Means of Concentration Index (CI)-Examples of Two Brazilian Sites. European Conference on Severe Storms, Helsinki, 3-7 June 2013, 7.

[33] Bhatta, B. (2010) Causes and Consequences of Urban Growth and Sprawl. In: Bhatta, B., Ed., Analysis of Urban Growth and Sprawl from Remote Sensing Data, Springer-Verlag, Berlin Heidelberg, 17-36. https://doi.org/10.1007/978-3-642-05299-6_2

[34] Kitoh, A., Endo, H., Kumar, K., Cavalcanti, I.F.A., Goswami, P. and Zhou, T. (2013) Monsoons in a Changing World: A Regional Perspective in a Global Context. Journal of Geophysical Research Atmospheres, 118, 3053-3065. https://doi.org/10.1002/jgrd.50258

[35] Nogués-Paegle, J. and Mo, K. (1997) Alternating Wet and Dry Conditions over South America during Summer. Monthly Weather Review, 125, 279-291. https://doi.org/10.1175/1520-0493(1997)125<0279:AWADCO >2.0.CO;2

[36] Herdies, D., da Silva, A. and Silva Dias, M.A.F. (2002) The Bi-Modal Pattern of the Summertime Circulation over South America. Journal of Geophysical Research Atmospheres, 107, 42-10. https://doi.org/10.1029/2001JD000997

[37] Silva, A.E. and Carvalho, L.M.V. (2007) Large-Scale Index for South American Monsoon (LISAM). Atmospheric Science Letters, 8, 51-57. https://doi.org/10.1002/asl.150

[38] Gan, M.A., Rao, V.B. and Moscati, M.C. (2006) South American Monsoon Indices. Atmospheric Science Letters, 6, 219-223. https://doi.org/10.1002/asl.119

[39] Raia, A. and Cavalcanti, I.F.A. (2008) The Life Cycle of the South American Monsoon System. Journal of Climate, 21, 6227-6246. https://doi.org/10.1175/2008JCLI2249.1

[40] Seth, A., Rojas, M. and Rauscher, S.A. (2010) CMIP3 Projected Changes in the Annual Cycle of the South American Monsoon. Climatic Change, 98, 331-357. https://doi.org/10.1007/s10584-009-9736-6 
Submit or recommend next manuscript to SCIRP and we will provide best service for you:

Accepting pre-submission inquiries through Email, Facebook, LinkedIn, Twitter, etc. A wide selection of journals (inclusive of 9 subjects, more than 200 journals)

Providing 24-hour high-quality service

User-friendly online submission system

Fair and swift peer-review system

Efficient typesetting and proofreading procedure

Display of the result of downloads and visits, as well as the number of cited articles Maximum dissemination of your research work

Submit your manuscript at: http://papersubmission.scirp.org/

Or contact ajcc@scirp.org 